\title{
Microcredit and Adjustment to Environmental Shock: Evidence from the Great Famine in Ireland
}

January 2016

Tyler Beck Goodspeed*

\begin{abstract}
The Great Famine of Ireland from 1845-51 ranks as one of the most lethal of all time, claiming approximately one eighth of the country's population. Utilizing Famine Relief Commission reports to develop a micro-level dataset of blight severity, I find that in the short run, districts more severely infected by blight experienced larger population declines and accumulations of buffer livestock by small- to medium-sized farms. In the medium and long runs, however, worse affected districts experienced greater substitutions toward other tillage crops and grazing livestock, particularly by small- to medium-sized farms. Using annual reports of the Irish Loan Funds, I further find that access to microfinance credit was an important factor in non-demographic adjustment to blight. Worse affected districts with at least one microfinance fund during the famine experienced substantially smaller relative population declines and larger relative increases in buffer livestock during and immediately after the famine, and greater relative medium- and long-run substitutions toward other crops and grazing livestock, than worse affected districts without a fund.
\end{abstract}

Keywords: microfinance, economic history, financial history, development, environment

* University of Oxford (tyler.goodspeed@economics.ox.ac.uk). I thank Richard Hornbeck, Cormac Ó Gráda, Joel Mokyr, Benjamin Friedman, Sean Barrett, Peter Solar, Liam Kennedy, Emma Rothschild, John Turner, Nathan Nunn, and seminar participants at LSE, MIT, Harvard, and Queens University Belfast for detailed comments and suggestions. I thank Aidan Hollis and Arthur Sweetman for generously sharing their data on the Irish Loan Funds, and Jenna Pace and Seth Rose for mapping support. I am also grateful to Will Hamilton for invaluable research assistance. 


\section{$1 \quad$ Introduction}

This paper analyzes adjustment by the undercapitalized, subsistence economy of nineteenthcentury Ireland to the shock of the Great Famine of 1845-51. The Great Irish Famine was the last major famine in Western European history. Claiming more than one million victims-one-eighth of Ireland's pre-famine population-the catastrophe ranks as one of the worst instances of mass starvation in modern history. Including more than one million who emigrated between 1845 and 1851, the island's total population fell by between $20-25 \%$, and has never since returned to its prefamine level. Phytophthora infestans, the fungal blight that devastated Ireland's potato crop during the famine, constituted a short- and long-run adverse shock to the staple crop of Irish agriculture, yet one that left all other crops, as well as grazing livestock, untouched. I therefore examine the short- and long-run effects of potato blight on changes in Irish population and agriculture, and in particular the role of credit constraints in hindering adjustment.

I find that population decline and accumulations of buffer livestock assets by small- to mediumsized farms constituted the primary short- and medium-run margins of adjustment to $P$. infestans, whereas the primary longer-run margins of adjustment were substantial and permanent substitutions away from potato cultivation toward other tillage crops and grazing livestock. Specifically, baronies severely or considerably infected by blight in 1845 and 1846 experienced population declines that were greater by 7004 and 4699 people by 1851 than moderately infected baronies, with the gap persisting through $1891 .{ }^{1}$ In the short and medium runs, small- to medium-sized farms in baronies severely or considerably affected by blight increased stocks of poultry and pigs-traditional buffers against crop failure-relative to analogous farms in moderately affected baronies, while in the long run more severe blight infection was associated with greater increases in holdings of grazing stock of cattle, sheep, and goats. Micro-variation in blight severity appears to have had no differential impact on changes in livestock holdings by the largest farms. Further, only after two successive harvest failures did more adversely impacted baronies begin to substantially reduce acreage under potato crop, with the potato's share of total tillage acreage in the long run declining by 15.7 and 12.3 percentage points more in severely and considerably versus moderately impacted baronies.

I also find that microfinance lending by the Irish Loan Funds played a significant role in nondemographic adjustment to blight, particularly for small- to medium-sized farms. The presence of at

${ }^{1}$ A barony is an Irish administrative unit, used mainly for cadastral purposes. It is larger than a township or civil parish, but smaller than a Poor Law Union or county. 
least one Loan Fund in a severely affected barony between 1845 and 1851 was associated with a 3661-person smaller relative population decline by 1851. Loan Fund lending in worse affected districts appears both to have enabled earlier relative crop substitutions away from the potato and the relative accumulation of larger buffer livestock holdings during and immediately after the famine. Specifically, by 1852, farms under 15 acres in severely affected baronies with a Loan Fund had increased pig and poultry holdings by $£ 673.23$ more than farms under 15 acres in baronies without a fund, relative to comparably sized farms in moderately affected baronies. Medium-run adaptation through relative increases in holdings of grazing livestock by farms under 15 acres was also greater in severely infected baronies with a Loan Fund versus those without. To address potential selection bias in the location of microloan funds, these results are estimated using an instrumental variables strategy that exploits the unique historical origins of these funds. Since the first Loan Fund was established by the Dublin Musical Society, which then briefly operated a loosely affiliated branch system of musical loan societies, I use the location of Association of Irish Musical Societies member organizations to instrument for the location of Loan Funds.

Building on Hornbeck (2012), which focuses on margins of adjustment in a more developed economy context and does not explore the possible effects of constrained credit on the time-path of adjustment in great depth, the results of this study demonstrate that access to credit plays an important role in short- and medium-run adjustment to adverse environmental shocks in a subsistence economy. The long-run non-demographic adaptations to the arrival of blight in Ireland, specifically crop portfolio diversification and substitutions away from tillage toward pasture, were effected earlier and to a greater extent in worse affected districts with a microcredit lender versus in those without. Moreover, in the presence of incomplete capital markets, access to microcredit appears to have allowed farmers to acquire temporary stocks of relatively cheap, liquid buffer livestock assets with low, but also low volatility, yields. This is significant because while recent research has demonstrated that access to microfinance credit can mitigate the impact of environmental shocks on income and consumption (Dercon 2002), most microfinance studies have focused on welfare effects and optimal models of sustainability under relatively ordinary lending circumstances.

Second, this study contributes to the extant literature on the debated role of livestock in smoothing consumption in developing contexts. While Rosenzweig and Wolpin (1993) and Verpoorten (2009) provide evidence for the use of bullocks by credit-constrained households in rural India and Rwanda as buffer stocks for consumption, Fafchamps, Udry, and Czukas (1998) find that 
livestock sales in Burkina Faso compensated for only $30 \%$ of income shortfalls due to adverse rainfall shocks, and Kazianga and Udry (2006) find little evidence of consumption smoothing. The results of this study, however, suggest that in analyzing the role of buffer livestock in consumption smoothing, it is important to distinguish between different types of livestock and their purpose for different types of farmers. Moreover, results indicate that the importance of buffer livestock may lie not so much in their liquidation value in the event of income shortfalls, as is typically reckoned, but rather in the hedging value of a low but relatively reliable supplemental income stream, for example with the sale of eggs from poultry stocks.

The organization of the remainder of this paper is thus as follows. Section 2 provides a historical summary of the Great Famine and the Irish Loan Funds. Section 3 outlines a conceptual framework of optimal land allocation and buffer livestock investment that incorporates credit constraints and uncertainty. Sections 4 and 5 detail data construction and the empirical framework, while Section 6 presents the results and additional robustness checks. Section 7 concludes.

\section{$2 \quad$ Historical Background}

\subsection{The Great Famine}

While instances of food shortages owing to periodic failure of the potato crop were not unknown in Ireland before 1845, such crises were typically geographically and temporally limited, with the statistical probability of successive failures negligible (Mokyr 1985; Solar 1989; Ó Gráda 1995, 1999). ${ }^{2}$ The risk of a one-off disappointing harvest thus did little to halt what Irish economic historian Austin Bourke called "a sinister trend toward monoculture," with the potato accounting for approximately $60 \%$ of the Irish food supply, and nearly $40 \%$ of Irish depending almost exclusively on the potato by the eve of the Great Famine (Bourke 1993). The proximate cause of the Great Famine, then, was the arrival in Ireland of the oomycte $P$. infestans in autumn 1845 . The disease, which rots the tubers of infected potatoes, most likely originated in the central Mexican highlands, traveling to Ireland via West Flanders, where in 1843 the provincial government funded importation of new potato varieties from the Americas. By late summer 1845, the fungus had spread throughout

\footnotetext{
${ }^{2}$ Solar (1989) finds pre-blight variation in French potato crop yields suggests the probability of a singular major failure was small and that, before the arrival of $P$. infestans, the probability of two or three successive failures was essentially nil.
} 
Flanders and neighboring regions in the Netherlands, northwestern France, lower Rhineland, Channel Islands, and southern England. On 6 September, press reports announced the first observations of potato disease in Ireland.

Affecting only potatoes, the disease was known as "late blight," as the effects typically do not become apparent until relatively late in the growing season. ${ }^{3} P$. infestans spores germinate on the leaves of potato plants, spreading to host tubers when temperatures rise above $10^{\circ} \mathrm{C}\left(50^{\circ} \mathrm{F}\right)$ and humidity over $75-80 \%$ for two or more days. By the time dark blotches on leaf tips and plant stems reveal the presence of blight, infection is already terminal and the plant will quickly decay. Entire fields can thus be destroyed in a matter of days. ${ }^{4}$ Since the potato was at the time primarily a subsistence crop, rapidly reproducing spores were typically spread by wind rather than by trade, traveling up to fifty miles a week (Koepsell and Pscheidt 1994). ${ }^{5}$

Though the relatively late arrival of blight in Ireland allowed roughly $60-70 \%$ of 1845 's aboveaverage potato crop to survive, in 1846, after an unusually damp spring and summer, potato crop failure was catastrophic, with an estimated $75 \%$ of the island's harvest lost to blight (Ó Gráda 1999). Yields recovered somewhat in 1847 , but the devastation of 1846 had left seed potatoes in scarce supply, which resulted in "Black " 47 " turning out to be the most deadly of the famine years. Moreover, after two years of potato crop failure, many Irish farmers had already been compelled to sell their scant livestock holdings, which meant stocks of pigs and poultry-traditional income buffers against adverse harvest fluctuations - were largely exhausted by $1847 .{ }^{6}$

While blight would reassert itself in 1848 and with less intensity in 1849 and, in certain regions, 1850, the winter of 1846-47 marked the worst of the disaster. By 1851 the outbreak had essentially run its course. However, although the blight receded after 1851, it nonetheless remained a persistent threat, with yields exhibiting considerably greater volatility than before 1845 . The 1872 and 1877-79 potato crops were particularly hard-hit, with many historians and contemporary observers reckoning

${ }^{3}$ Blight can also affect tomatoes, but tomatoes were rarely grown in pre-famine Ireland, and there is no mention in the historical literature of the effect of blight on negligible tomato cultivation in Ireland.

${ }^{4} P$. infestans spores winter on tubers of the previous year's crop that have been left in the ground as seed or in cull piles. Attempts at early harvest of an infected crop are likely to be in vain, as infected tubers will deteriorate quickly in storage (Zwankhuizen, Govers, and Zadoks 1998).

5 P.infestans remains difficult to manage even today. Genetic engineering of resistant varieties, proper field hygiene, and use of fungicides are common tools for preventing or combating blight, but continually evolving resistance remains a challenge (Zwankhuizen, Govers, and Zadoks 1998).

${ }^{6}$ Given that successive crop failures were virtually unheard of before 1845, many farmers expanded potato plantings in 1846, confident of the improbability of back-to-back failure. Livestock were rarely consumed directly, but rather sold as pork, eggs, and butter to national and international markets, with the proceeds used to buy cheaper food substitutes (Ó Gráda 1995, 1999). 
the failure of the 1879 harvest comparable to that of 1846 (Davidson 1933; Bourke 1960). ${ }^{7}$ Moreover, the persistent presence of blight meant a permanent drop in normal per-acre yields from pre-famine levels (Ó Gráda 1995). Bourke (1993) estimates that save a few notable exceptions it was not until the mid- $20^{\text {th }}$ century that annual potato crop yields again attained pre-1845 levels. Before 1845, potato yields per acre averaged 6-7 tons. During the post-famine period from 1856 to 1880, average annual yield was only 3.2 tons per acre. Even after the discovery of copper sulphate as a partially effective antidote in 1882, yields did not fully recover to pre-famine levels; on the eve of the First World War, per-acre yields were still just under 5 tons (Ó Gráda 1995).

Long-run vulnerability to blight was, however, unevenly distributed. While the spread of $P$. infestans spores was indiscriminate, the severity of blight infection was not. $P$. infestans thrives in moist, temperate, and humid conditions, hence why the unusually wet summers of 1846 and 1879 were exceptionally favorable to blight (Bourke 1965b). Consequently, regions whose typical climatic conditions, particularly in late summer, were especially hospitable to blight faced permanently higher probabilities of reduced harvests. Thus, in addition to inflicting a major transitory shock on the Irish agricultural economy, the arrival of blight also constituted a permanent, regionally variated, adverse disturbance both to normal potato yields, and to yield volatility.

\subsection{Microcredit and the Great Famine}

Given its magnitude and enduring impact, much has been written about the Great Famine. ${ }^{8}$ Relatively little, however, has been written of the severely underdeveloped Irish financial system, and thus the potential role of missing or incomplete capital markets in hindering the ability of Irish farmers to absorb a major environmental shock. Particularly neglected until recently are the Irish Loan Funds-privately-run microfinance funds operating throughout Ireland from the mid-18th century into the early 20th century. Originally conceived by Irish essayist and satirist Jonathan Swift in the early 1700s, the first Loan Fund was established as a quasi-charitable enterprise by the Musical Society of Dublin, which for a brief time thereafter operated a branch system of musical loan societies. By the early 1840s, however, the Loan Funds were a diverse set, including private pawnbrokers and Mont-de-Piétés that had reorganized and registered as Loan Funds, and with no

\footnotetext{
7 The harvests of 1860-2, 1890, 1894, and 1897 were also especially adversely affected by blight.

${ }^{8}$ See, in particular, Hansen (1940), Mokyr (1985), Bourke (1993), Ó Gráda (1995, 1999). 
operating connection to the original Dublin society (McLaughlin 2009). ${ }^{9}$ On the eve of the famine there were thus 300 independent Loan Funds active in more than half of Ireland's 323 baronies, extending almost 500,000 loans a year to approximately 300,000 borrowers, or $4 \%$ of Ireland's prefamine population. Assuming an average family size of five, this implies Loan Funds were annually extending loans to roughly $20 \%$ of Irish households, though in some counties the figure was closer to 30-40\% (Hollis and Sweetman 1998, 2004).

Like more contemporary microfinance models, the Irish Loan Fund model was predicated on extending small, short-term loans with frequent payments, secured by two cosignatories in lieu of collateral. The typical fund made 1,750 loans a year, with an average loan size of approximately $£ 3$ and a fixed maximum of $£ 10 .{ }^{10}$ In comparison, before the famine just two Irish joint-stock savings banks, the Agricultural and Commercial Bank and Provident Bank, had ventured into the business of extending loans below $£ 10$; both had failed by 1845 . Consequently, on the eve of the famine, Loan Funds were among the few formal lending institutions in Ireland extending loans in amounts smaller than per capita income, which Mokyr (1985) estimates at between $£ 9.50$ and $£ 10.50 .{ }^{11}$

Standard loan term was 20 weeks, with mandatory weekly payments, enforced by penalty fines. Cosignatories, who were not allowed to borrow themselves or cosign another loan so long as they were bound by cosignature to an outstanding loan, could be pursued in the event of default, with $2 \mathrm{~s}$. deducted from the pay of staff members who failed to initiate legal proceedings against delinquent cosignatories to a defaulted loan (Piesse 1841). ${ }^{12}$ Interest was standardized to $4 \mathrm{~d}$. in the pound per week, or $8 \%$ per annum, though additional fees for filing application cards and promissory notes, and for screening sureties, raised effective rates to $9-12 \%$, with penalties for late payments potentially adding a further 1-5 percentage points on an annualized basis. ${ }^{13}$ Lending was explicitly intended for low-income, rural borrowers, with small farmers, cottiers, and agricultural laborers comprising the majority of loan recipients.

From 1838, funds were overseen by a central board, the Loan Fund Board, that standardized

9 Traditional pawnbrokers and Mont-de-Piétés had different lending structures than Loan Funds, and, unlike Loan Funds, required collateral, which meant that potential borrowers had to possess durable assets to pledge.

10 To put these figures in perspective, Thom's Statistics of Ireland for 1853 quotes the following official enumerated values: cattle at $£ 6.50$ per head, pigs at $£ 1.25$ per head, sheep at $£ 1.10$ per head, goats at $£ 0.375$ per head, and chickens at $£ 0.025$ per head. Market quotes from 1845 , however, report $£ 2.25$ per head for pigs ( $£ 1.00$ for a young feeder pig), $£ 0.09$ per head for chickens, $£ 9.00$ per head for an adult cow, and $£ 1.00$ to $£ 2.10$ for an adult sheep, depending on gender. Alternatively, seed to sow one acre of oats cost $£ 0.90$ (Thom's 1850).

${ }^{11}$ Mokyr (1985) estimates pre-famine Irish per capita income at the $67^{\text {th }}$ percentile was between $£ 4.30$ and $£ 4.60$.

12 There were 12 pence (d.) in a shilling, and 20 shillings (s.) in a pound ( $£$ ). Legally, Loan Funds enjoyed priority over other creditors in the event of debtor bankruptcy (McLaughlin 2009).

${ }^{13}$ Interest was originally set at $6 \mathrm{~d}$. in the pound, or $12 \%$ on an annualized basis, though was reduced in 1843. 
rules and accounting practices, though management and operations remained decentralized. Funds were managed by paid clerks, and funded by interest-earning deposits, retained earnings, interest-free loans, and charitable donations (Hollis and Sweetman 1998). A standard 5\% annual rate on deposits (reduced from $6 \%$ in 1843)-nearly twice the rate typically offered by conventional joint-stock banks-allowed the Loan Funds to attract considerable depositor interest. The majority of depositors, however, in contrast to borrowers, were large depositors. Piesse (1841) notes that most depositors held deposits of $£ 50$ or more, an observation confirmed by McLaughlin (2009), who finds that $44 \%$ of depositors in 1840 held $£ 50$ or more, with a further $20 \%$ holding between $£ 10$ and $£ 20$. Loan Fund debtors and creditors were therefore for the most part drawn from non-overlapping economic sectors and income strata.

Still, given their predominantly low-income, agrarian clientele and the high spatial correlation of the environmental shock to agricultural incomes, many Loan Funds struggled during the famine years as elevated default risk following repeated crop failures necessitated substantial deleveraging (Goodspeed 2015). Of the 300 funds operating in 1843, only 123 remained by 1851, while the average amount circulated per fund fell from $£ 6,197$ in 1845 to $£ 2,438$ in 1847 . The following year, 58 funds had to close. Nonetheless, many funds remained active throughout the famine years, and those that survived quickly recovered and returned to profitability. Even during the worst years of 1846 and 1847, Loan Funds managed to extend 459,360 and 223,465 loans, providing, respectively, £1,712,638 and $£ 834,855$ of credit to Ireland's rural poor. ${ }^{14,15}$

\section{Conceptual Framework}

The arrival of blight in Ireland was a major shock that permanently affected potato yields. Not only were per-acre yields permanently lower after 1845, they were also subject to much higher volatility. The conceptual framework underpinning the empirical analysis therefore supposes a representative farmer must determine his optimal allocation of land among alternative crops and pasture with unequal yields and variances so as to maximize his expected net return per acre while

\footnotetext{
14 Hollis and Sweetman (2004) find that prudential management before the famine was the most important predictor of fund survival; the maintenance of lower leverage ratios before the famine and having non-clergy managers were strongly associated with survival, while population decline and pre-famine measures of wealth and poverty were poor predictors. Goodspeed (2015) confirms these findings.

${ }^{15}$ In the first two years of the famine, Loan Funds extended an average of 2,375 and 3,297 loans in baronies with a mean pre-famine population of 30,876. In 1849, Loan Funds still extended an average of 1,886 loans per fund. Cumulatively during the famine years, Loan Funds extended one loan for nearly every two men, women, and children of the 1841 population, with a mean loan size of $£ 3.56$.
} 
minimizing risk, subject to constrained credit and uncertainty over whether yield and/or yield volatility shocks are permanent or transitory. In addition to the land allocation choice between different tillage crops and pasture, I further suppose that the farmer can invest in non-grazing (and therefore non-acreage consuming) "buffer" livestock yielding a risk-free return, since Rosenzweig and Wolpin (1993), Dercon (1996), Fafchamps, Udry, and Czukas (1998), and others have demonstrated that agricultural households often keep livestock as buffer assets to smooth consumption when income is stochastically variable and capital markets incomplete. ${ }^{16}$ Bourke (1993) and Rosen (1999) demonstrate that this was also true of nineteenth-century Irish agriculture, with pigs and poultry constituting the most common buffer assets.

More formally, I suppose the farmer faces a choice between two crops, $i$ and $j$, with yields $Y_{i, j t}=y_{i, j}(Z)+\eta_{i, j t}$, where $y_{i, j}(Z)$ is expected yield, $Z$ a vector of soil and other plot characteristics, and $\eta_{i, j t}$ a mean zero, serially independent disturbance term, with variance, $\lambda_{i, j}^{2}$, that captures deviation from true yield obtaining under normal growing conditions. ${ }^{17}$ Not knowing true yield, the farmer must form yield estimates, $\hat{y}_{i, j t}$, with variance $\sigma_{i . j t}^{2}$, based on all information pertaining to expected yields received up to the start of year $t$. Given output prices, $p_{i t}$ and $p_{j t}$, variable input costs, $c_{i t}$ and $c_{j t}$, a per-acre cost $k$ of converting acreage that had been planted with crop $j$ in $t-1$ to crop $i$ (or vice versa) in year $t$, and total available acreage, $\bar{A}$, the farmer chooses optimal acreage, $A_{i t}^{*}$, to allocate to crop $i$ so as to maximize the utility of expected profit in each period. In addition, he must choose the optimal number of non-acreage consuming buffer livestock, $L_{t}^{*}$, to invest in, given period $t$ unit purchase and sale prices of $c_{L t}$ and $p_{L t}>c_{L t}$.

Finally, since Feder (1980), de Janvry, Fafchamps, and Sadoulet (1991), Gine and Klonner (2005), Foster and Rosenzweig (2010), and Kinnan and Townsend (2012) have demonstrated the importance of credit constraints in acreage allocation and consumption smoothing, I assume that

16 The zero-acre assumption is admittedly unrealistic, since chickens and pigs, though requiring only a negligible acreage allocation, did consume some portion of tillage output as fodder (Bourke 1993). Nonetheless, I assume a zeroacre requirement for buffer livestock in order to keep the analysis simple, and to reflect that pig and poultry diets were often supplemented by foraging. In the wild, pigs will eat leaves, grasses, roots, fruits and flowers, while chickens consume wild seeds, insects, and occasionally mice. Thom's almanac reports that pigs "will thrive on the refuse garbage of the farm, such as mangel, and Swedish turnip tops, and such portions of the roots as the cattle do not consume" (Thom's 1850). Pork, poultry, and eggs thus continued to be exported during the famine as Irish farmers used revenue from these buffer stocks in order to purchase cheaper food substitutes, such as imported Indian corn.

${ }^{17}$ Because the disturbance term $\eta_{i, j t}$ has a mean of zero, a permanent adverse yield shock that increases $\lambda_{i, j}^{2}$ also implies a lower $y_{i, j}$. In the short run, this means a larger $\sigma_{i, j t}^{2}$, as the farmer's yield estimates only converge to $y_{i, j}$ over time. Alternatively, rather than assume $\eta_{i, j t} \sim N\left(0, \lambda_{i, j}^{2}\right)$, we could adopt a mean-variance-skewness or mean-varianceskewness-kurtosis approach to account for the fact that a permanent adverse shock may involve a leftward skewing and peakedness of the variance of the disturbance term. The assumption of non-normality, however, introduces needless cumbersomeness, and reinforces the predictions of the baseline model; assuming the farmer is risk averse, a left-tail shock to yield variance of crop $i(j)$ will induce substitutions toward $\operatorname{crop} j(i)$, as well as to buffer livestock. 
whatever portion of the sum of fixed and variable costs exceeds the farmer's wealth at the start of year $t, \omega_{t}$, he must finance via borrowing (i.e. cash expenditure cannot exceed cash availability from initial resources plus credit). Given an interest rate $r$ and credit limit $\bar{K}$, the farmer's problem is then to maximize utility of expected profit, $\pi(\psi, \Sigma)$, where

$$
\psi \equiv \psi_{i t} A_{i t}+\psi_{j t}\left(\bar{A}-A_{i t}\right)+\left(p_{L t}-c_{L t}\right) L_{t}-r\left(\left|A_{i t}-A_{i t-1}\right| k+c_{i t} A_{i t}+c_{j t}\left(\bar{A}-A_{i t}\right)+c_{L t} L_{t}-\omega_{t}\right)
$$

and, with correlation coefficient $\rho_{i j}$ between crops $i$ and $j$,

$$
\Sigma \equiv\left(\lambda_{i}^{2}+\sigma_{i t}^{2}\right) A_{i t}^{2}+\left(\lambda_{j}^{2}+\sigma_{j t}^{2}\right)\left(\bar{A}-A_{i t}\right)^{2}+2 A_{i t}\left(\bar{A}-A_{i t}\right)\left(\lambda_{i}+\sigma_{i t}\right)\left(\lambda_{j}+\sigma_{j t}\right) \rho_{i j}
$$

subject to the constraint $\left.\left(\left|A_{i t}-A_{i t-1}\right|\right) k+c_{i t} A_{i t}+c_{j t}\left(\bar{A}-A_{i t}\right)\right) \leq \omega_{t}+\bar{K}$. Assuming the farmer is risk averse, $\pi(\psi, \Sigma)$ is increasing in $\psi$ and decreasing in $\Sigma$.

Conceptualizing the farmer's choice in this way yields several predictions. ${ }^{18}$ First, a relative decline in the expected yield of a particular crop will result in substitutions toward alternative forms of land use, whether other crops or grazing livestock. Second, a relative increase in the expected yield volatility of a particular crop will likewise induce substitutions toward other crops or grazing livestock. Third, a relative decline in the expected yield of a given crop and/or relative increase in the expected yield volatility of that crop will induce larger holdings of "buffer" livestock. However, fourth, this substitution effect toward buffer livestock will be particularly pronounced in the short run, since in the long run, through repeated observation, the variance of the farmer's estimates of expected crop yields will fall. Finally, fifth, all three primary avenues of non-demographic adjustment-substitutions toward pasture and other tillage crops, as well as short-run accumulation of buffer livestock - will be impeded by a higher cost of capital or binding credit constraint. ${ }^{19}$

\section{$4 \quad$ Data Construction}

This study utilizes original data from numerous archival sources. First and foremost, since there was no previous indicator of micro-variation in blight, I construct an index of blight severity at the baronial level using constabulary reports from the Distress Papers of the Parliamentary Relief

${ }^{18}$ For full elaboration of the model and formal derivation of predictions, see Goodspeed (2014).

${ }_{19}$ Note that the framework is sufficiently flexible to allow for a non-market, pure subsistence farm. In the pure subsistence case, we can consider yields and variable costs in caloric terms, with $p_{i, j t} \equiv 1$. Adding a subsistence constraint, $y_{i t} A_{i t}+y_{j t}\left(\bar{A}-A_{i t}\right) \geq y_{\min } \bar{A}$, where $y_{\min }$ represents the minimum per-acre yield for a farm of size $\bar{A}$ to allow for bare subsistence, we see that we must also evaluate potential corner solutions at $A_{i t}=0$, which will occur if $\left({ }^{\left.y_{\min }-y_{j i t} / y_{y i t}-y_{j t}\right)}<0\right.$, and $A_{i t}=\bar{A}$, which will occur if $y_{i t}=y_{\min }$. In the event of a corner solution, acreage reallocation will only occur if there is a relaxation of the subsistence constraint, meaning either an increase in $\bar{A}$ or decline in in $y_{\text {min. }}$. 
Commission. ${ }^{20}$ The Relief Commission was established by the British government in November 1845 in response to the failure of the potato crop in Ireland, in order to advise the government concerning the extent of potato loss and distress in Ireland, to oversee the storage and distribution of emergency Indian corn and meal, and to administer the activities of local relief committees. In practice, though, the commission had little real authority beyond coordinating the collection of data. To discharge its duties, the commission regularly solicited reports from local officials regarding the state of the potato crop, extent of blight infection, and the condition of the local populace. Reports and incoming letters were received from local constables, coast guard officials, lieutenants of counties, resident magistrates, and Poor Law guardians.

To assess the level of local blight severity, I rely on reports received between November 1845 and August 1846, when the commission was disbanded, with most reports received in July/August 1846. Based on these reports, I designate each barony as low, medium, or high impact, corresponding to moderate, considerable, or severe blight infection. In the case of quantitative reports, I define a low or moderate impact barony as a barony with less than one-third of its potato crop infected by blight. Medium or considerable impact baronies are baronies with a one-third to two-thirds infection rate, and high or severe impact baronies experienced crop infection rates in excess of two-thirds. For baronies with only qualitative reports, I use language such as "very good," "trifling," and "partially infected" to designate low-impact baronies; "considerably infected" or "very much infected" to designate medium-impact baronies; and "generally very bad," "extensively infected," and "very extensively infected" to designate high-impact baronies. ${ }^{21}$ A representative report is provided in Figure 1, and the geographic dispersion of blight severity is illustrated in Figure $2 .{ }^{22}$

Reports issued at the larger administrative unit of Poor Law Union (PLU) I assign to baronies according to the location of the reporting official. In increasing order of size, Irish administrative units proceed from townland to civil parish to barony to PLU to county to province. Several baronies were split or merged after 1851. For those that split, I sum statistics for the successor

\footnotetext{
${ }^{20}$ Previous studies have used estimated excess mortality as a proxy for blight severity, but that method is flawed because mortality is itself an outcome variable.

21 The majority of reports, like the sample provided in Figure 1, consist of both qualitative and quantitative assessments of blight severity. To ensure equivalent coding of qualitative and quantitative reports, I rely on these mixed reports to link particular vocabulary with corresponding quantitative accounts. For example, "extensively" and "generally" were universally associated with estimated crop infection rates in excess of $75 \%$, whereas "considerably" and "very much" or "quite" were typically associated with infection rates near $50 \%$. Nonetheless, in Table 2 , below, I include a categorical variable for whether a report was qualitative, quantitative, or both to test for whether the type of report explains variation in blight index scores. It does not.

${ }_{22}$ Note that many baronies do not appear in the sample. This is because there were no surviving reports in the Relief Commission papers for these baronies. Numerous official Irish records were lost in June 1922, during the Irish Civil War, when the Public Record Office was destroyed by fire.
} 
baronies to preserve continuity. For those that merged, I sum statistics for the predecessor baronies and weight blight index scores by predecessor area. Altogether, I am thus able to assign a blight severity designation to 255 of the 323 baronies in Ireland on the eve of the famine, representing all four Irish provinces, all 32 counties, and 105 of 163 PLU's. The main sample is therefore a panel of these 255 baronies from 1821 to 1891. Since some years and outcome variables lack baronial-level data, I also classify each PLU as suffering low-medium or medium-high blight severity, based on averages of constituent baronial levels, weighted by area. ${ }^{23}$ This secondary sample is a panel of 105 PLU's from 1844 to $1891 .^{24}$

Data on lending activity by the Irish Loan Funds is from the annual reports of the Commissioners of the Loan Fund Board of Ireland. Pre-Famine baronial valuations are from the 1845 Appendix to the Minutes of Evidence taken before Her Majesty's Commissioners of Inquiry into the State of the Law and Practice in Respect to the Occupation of Land in Ireland. ${ }^{25}$ Unfortunately, data on farm size do not exist at the baronial level before the arrival of blight in 1845 . However, the Appendix to the Minutes of Evidence lists the number of landholders in each PLU by holding size. ${ }^{26}$ An additional constraint is that, for landholdings of 5 to 50 acres, while the returns listed in the Minutes of Evidence divide at 5, 10, and 20 acres, returns from the agricultural surveys of 1848-50 divide at 15 and over 30 acres, and returns after 1850 divide at 15, 30, and 50 acres. It is therefore only possible to consistently analyze changes in the share of total farmholdings under 1 acre and between 1 and 5 acres. Livestock prices are compiled from Alexander Thom's Statistics of Ireland, from Thom's Irish Almanac and Official Directory, an annual almanac of Irish statistics. All other baronial- and PLU-level data were assembled using the decennial Census of Ireland (1821-1891), Returns of Agricultural Produce in Ireland (1847-1856), and Agricultural Statistics of Ireland (18571871). ${ }^{27}$ Summary statistics are reported in Table 1.

It is important to note that by the time the outbreak had run its course in 1851, virtually no part of Ireland had been completely spared. My index of blight severity solely measures blight

\footnotetext{
${ }^{23}$ Because aggregating blight observations at the PLU level leaves no exclusively low or moderately affected observations, I have to reclassify blight severity as a single binary variable.

${ }^{24}$ For baronial-level analysis of average changes in crop acreage, the main panel includes the years 1844 through 1871, and the years 1847 through 1871 for average changes in the value of livestock holdings. For PLU-level analysis of average changes in farm size, the secondary panel includes the years 1845 through 1871.

${ }^{25}$ The Minutes of Evidence were the official report of the Devon Commission appointed by the government of Sir Robert Peel to research landholding in Ireland. The commission was headed William Courtney, the 10th Earl of Devon.

${ }^{26}$ Minutes of Evidence were submitted to the British House of Lords on 5 May 1845, before the arrival of blight.

27 All three surveys were commissioned by Parliament, and have been digitized by Clarkson et al. for the Database of Irish Historical Statistics. For full documentation see Clarkson et al. (1997).
} 
severity in 1845 and 1846 in observed baronies. Baronies designated as moderately or considerably impacted may subsequently have become severely impacted as blight spread throughout the island. However, insofar as variation in blight severity in 1845 and 1846 reflected variation in climatic hospitability to blight, observations of blight severity in 1845-46 will reflect both short- and long-run exposure to blight. ${ }^{28}$

To confirm this correspondence between microvariation in blight severity in 1845 and 1846 and long-run susceptibility to blight, in Figure 4 I plot per-acre potato yield data at the Poor Law Union level from a preliminary Parliamentary report of the 1879 Returns of Agricultural Produce in Ireland survey against blight severity in 1845-46. The failure of the 1879 harvest is generally reckoned to have been comparable to that of 1846 owing to particularly bad outbreaks of $P$. infestans (Davidson 1933; Bourke 1960). The graph reveals a strong negative correlation between blight severity in 184546 and 1879 per-acre potato yields - higher blight severity in 1845-46 was associated with a 238.459pound lower per-acre yield in 1879-consistent with long-run vulnerability to blight varying by location.

Though there is no historical evidence that either the incidence of blight severity or location of Loan Funds was correlated with non-fixed baronial characteristics that were also correlated with post-famine outcomes, to test these identifying assumptions I regress blight severity, Loan Fund presence, and average annual Loan Fund lending during the first five years of the famine (1845-50) on pre-famine baronial characteristics, with results presented in Table $2 .{ }^{29}$ To test whether my blight severity index maps onto late-summer climatic conditions hospitable to blight, I also regress blight severity on local average July air and soil temperature and humidity. ${ }^{30}$ Finally, to test for coding consistency, I include a categorical variable for whether the blight report was qualitative, quantitative, or both.

OLS-estimated coefficients presented in column 1 of Table 2 indicate that pre-famine baronial characteristics are poor predictors of blight severity. None of the estimated coefficients for baronial literacy, population density, potato crop share, fourth-class housing, or religious diversity are

\footnotetext{
${ }^{28}$ Consistent with this, Cousens $(1960 \mathrm{~b}, 1962,1964)$ finds that after the near universal distress of 1847 , prefamine poverty conditions exerted negligible influence on excess mortality, emigration, and conjugal statistics, as distress was determined more by local conditions of the potato harvest.

${ }^{29}$ I include a Herfindahl index of religious diversity in 1861, the first year for which data on religious affiliation is available, as a proxy for social capital. The variable is thus $R=\sum_{i=1}^{N} p_{i}^{2}$, where $p_{i}$ is the proportion of all religious affiliates belonging to denomination $i$ and $N$ is the number of religious denominations.

${ }^{30}$ In the absence of pre-famine climate data, I use contemporary averages from Met Éireann, the Irish National Meteorological Service.
} 
statistically significant, and the fit is poor. ${ }^{31}$ Estimated coefficients on the potato crop share of total crop acreage and fourth-class housing indicate that officials were no more likely to report severe blight infection where potato dependence was higher and poverty greater. The estimated coefficient on baronial valuation is statistically significant, though it is small in size and significant only at the $10 \%$ level. While mean July soil temperature is not a statistically significant predictor of blight severity, the estimated coefficients for mean air temperature and humidity are positive and statistically significant, which is consistent with slightly warmer, more humid late-summer atmospheric conditions being more hospitable to spore germination. Whether a report was qualitative, quantitative, or both does not appear to have had an effect on assessed blight severity.

Estimated coefficients presented in columns 2 and 3 of Table 2 indicate that pre-famine characteristics are also poor predictors of the presence of at least one active Loan Fund and average annual Loan Fund lending during the famine years. None of the estimated coefficients in column 2 are statistically significant, and the fit is poor. In column 3 , higher pre-famine population density, which Mokyr (1985) and Ó Gráda (1997) use as a proxy for poverty, is positively associated with the volume of Loan Fund lending, though the remaining variables are not correlated with differential microcredit supply during the famine. Notably, social capital, as proxied by a Herfindahl index of religious diversity, appears to have had no statistically significant effect either on Loan Fund presence or the scale of Loan Fund lending during the famine.

\section{$5 \quad$ Empirical Framework}

Following Hornbeck (2012), the empirical analysis is based, first, on estimating average changes in baronies more severely infected by blight relative to less severely infected baronies, and, second, estimating average relative changes in more severely infected baronies with a Loan Fund relative to those without, in the same county and PLU and with similar pre-famine characteristics.

To estimate average changes by blight severity, each outcome $Y_{b t}$ in barony $b$ and year $t$ is differenced from its pre-famine value $Y_{\text {bpre }}$ in order to construct a panel at the baronial level spanning, depending on data availability for the relevant outcome variable, the years 1841 through 1891. Each difference is regressed on binary variables for medium and high blight severity ( $B_{b}^{\text {med }}$ and

\footnotetext{
${ }^{31}$ In the Census of Ireland, fourth-class houses are defined as "all mud cabins having only one room."
} 
$\left.B_{b}^{\text {high }}\right)$, pre-famine baronial characteristics $\left(X_{b}\right)$, categorical variables for county $\left(C_{t}\right)$ and PLU $\left(P L U_{t}\right)$, and an error term $\left(\varepsilon_{b t}\right)$ :

$$
Y_{b t}-Y_{b p r e}=\beta_{1 t} B_{b}^{\text {med }}+\beta_{2 t} B_{b}^{\text {high }}+\theta_{t} X_{b}+C_{t}+P L U_{t}+\varepsilon_{b t}
$$

The coefficients of interest, $\beta_{1 t}$ and $\beta_{2 t}$, are indexed by $t$ to allow for the estimated effects of medium and high blight infection to vary over time.

Since farm size data before 1845 and crop data from 1847-51 and after 1871 are not available at the baronial level, I also estimate a modified Eq. (1) at the higher observational level of PLU. Because aggregating blight observations at the PLU level leaves no exclusively moderately affected observations, I reclassify blight severity as a single binary variable, with PLU's experiencing either medium-high (considerable to severe) or low-medium (moderate to considerable) blight infection in 1845 and $1846 .{ }^{32}$ Each outcome, $Y_{u t}$, in PLU $u$ and year $t$ is then differenced from its pre-famine value, $Y_{\text {upre }}$, in order to construct a panel at the PLU level spanning the years 1844 through 1891, and the difference regressed on blight severity $\left(B_{u}^{\text {med-high }}\right)$, pre-famine PLU characteristics $\left(X_{u}\right)$, a categorical variable for county $\left(C_{t}\right)$, and an error term $\left(\varepsilon_{u t}\right)$ :

$$
Y_{u t}-Y_{\text {upre }}=\beta_{t} B_{u}^{\text {med-high }}+\theta_{t} X_{u}+C_{t}+\varepsilon_{u t}
$$

To evaluate the effect of access to credit, estimates of average changes by Loan Fund activity are then obtained by regressing each differenced outcome in barony $b$ and year $t$ on binary variables for medium and high blight severity ( $B_{b}^{\text {med }}$ and $B_{b}^{\text {high }}$ ), average annual Loan Fund lending from 1845 to $1850\left(L_{b}\right)$, the fraction of total baronial border length shared with other baronies with at least one Loan Fund during the famine $\left(B O R D_{b}\right)$, pre-famine baronial characteristics $\left(X_{b}\right)$, categorical variables for county $\left(C_{t}\right)$ and PLU $\left(P L U_{t}\right)$, and an error term $\left(\varepsilon_{b t}\right)$. Additionally, Loan Fund lending is interacted with blight severity and lags of baronial outcomes $\left(y_{b t-n}\right): 33$

$$
\begin{aligned}
Y_{b t}-Y_{b p r e} & =\beta_{1 t} B_{b}^{\text {med }}+\beta_{2 t} B_{b}^{\text {high }}+\beta_{3 t} L_{b}+\beta_{4 t} L_{b} \times B_{b}^{\text {med }}+\beta_{5 t} L_{b} \times B_{b}^{\text {high }} \\
& +\gamma_{1 t} y_{b t-n}+\gamma_{2 t} L_{b} \times y_{b t-n}+B O R D_{b}+\theta_{t} X_{b}+C_{t}+P L U_{t}+\varepsilon_{b t}
\end{aligned}
$$

In section 6.2, I also estimate Eq. (3) replacing average annual Loan Fund lending during the famine with a binary variable for Loan Fund presence during the famine. Since farm size data before 1845 and crop data from 1847-51 and after 1871 are not available at the baronial level, I again estimate

32 To reclassify blight severity at the PLU level, I average constituent baronial-level blight observations coded 0 , 1, or 2 for low, medium, or high blight severity, weighted by baronial area. PLU's with an average $>1.5$ are classified as medium-high impact PLU's (very considerably to severely impacted), while PLU's with an average of $<1.5$ are classified as low-medium impact (moderate to considerable infection).

${ }_{33}$ The lags of baronial outcomes are for available pre-famine survey years excluding the immediately preceding survey year, $Y_{\text {bpre. }}$ 
changes at the PLU level. Modifying Eq. (3), each outcome, $Y_{u t}$, in PLU $u$ and year $t$ is differenced from its pre-famine value, $Y_{\text {upre }}$, and the difference regressed on blight severity $\left(B_{u}^{\text {med-high }}\right)$, a binary variable for Loan Fund presence during any one of the preceding famine years $\left(L_{u}\right)$, the fraction of total PLU border length shared with other PLU's with at least one Loan Fund during the famine $\left(B O R D_{u}\right)$, pre-famine PLU characteristics $\left(X_{u}\right)$, a categorical variable for county $\left(C_{t}\right)$, and an error term $\left(\varepsilon_{u t}\right)$. Additionally, Loan Fund presence is interacted with blight severity and with lags of PLU outcomes $\left(y_{u t-n}\right)$

$$
\begin{aligned}
Y_{u t}-Y_{u p r e} & =\beta_{1 t} B_{u}^{\text {med-high }}+\beta_{2 t} L_{u}+\beta_{3 t} L_{u} \times B_{u}^{\text {med-high }} \\
& +\gamma_{1 t} y_{u t-n}+\gamma_{2 t} L_{u} \times y_{u t-n}+B O R D_{u}+\theta_{t} X_{u}+C_{t}+\varepsilon_{u t}
\end{aligned}
$$

Finally, as a falsification exercise, in section 6.3 I estimate Eqs. (3) and (4) using the number of banks in 1843 in lieu of Loan Fund presence or lending. The samples are balanced in each regression, meaning every included barony or PLU has data in every analyzed time period. ${ }^{34}$

First differencing allows us to control for unobservable baronial or PLU characteristics that vary across baronies but are fixed over time, while county and PLU categorical variables allow us to control for unobservable variables that vary by year but are constant across administrative units. For non-fixed but observable baronial characteristics, the included controls in Eqs. (1) through (4) are area, 1841 population, baronial valuations completed by 1845, adult literacy rate (reading, writing, or both) in 1841, the potato crop share of total tillage acreage in 1844, and the fraction of housing rated fourth class in the 1841 census. In the absence of income or wealth statistics, these variables are included as proxies for development and poverty. Acreage under potato crop as a share of total tillage acreage in 1844 is also included to allow baronies similarly impacted by blight but with different pre-famine levels of potato dependence to experience systematically different changes after 1845. Each regression furthermore includes the relevant outcome variable in the most proximate pre-famine year and all available pre-famine periods to control for possible pre-trends. ${ }^{35} \mathrm{In}$ Eqs. (3) and (4), Loan Fund lending is interacted with lagged outcomes to allow for the possibility that Loan Fund activity may have had more or less of an effect where there were already more

\footnotetext{
${ }^{34}$ For two time periods, first-difference and fixed-effects estimators are numerically equivalent. As with fixed effects, first-differencing eliminates time-invariant baronial characteristics and thereby yields consistent and unbiased estimators. Differencing is more efficient when the untransformed error term more closely follows a random walk. Clustering corrects for any possible serial correlation in the errors.

35 Though the main sample of blight severity includes 255 observations at the baronial level, and the secondary sample includes 105 observations at the PLU level, the number of observations for all baronial and PLU regressions are fewer than 255 and 105, respectively. This owes to the fact that baronies or PLU's missing pre-famine observations of included outcome or control variables are automatically excluded.
} 
people and/or tillage acres under potato crop. ${ }^{36}$ Including the fraction of total baronial or PLU border length shared with other baronies or PLU's with at least one Loan Fund during the famine allows us to control for possible spatial autocorrelation or border effects.

Along these observable dimensions, in Eqs. (1) and (2), baronies and PLU's differentially afflicted by blight are allowed to experience systematically different changes after 1845 . The identification assumption is that baronies and PLU's with different blight infection rates but in the same region and with similar pre-famine characteristics would have experienced similar changes after 1845 if not for blight. In Eqs. (3) and (4), baronies and PLU's with or without a Loan Fund, or with different levels of Loan Fund lending during the famine, are likewise allowed to experience systematically different relative changes after 1845, with the identification assumption that districts with or without a Loan Fund, or with more or less Loan Fund lending during the famine, but in the same region and with similar pre-famine characteristics and levels of blight infection would otherwise have followed similar trajectories in population change and adjustment in land use if not for differential access to Loan Fund credit.

The coefficients $\beta_{4 t}$ and $\beta_{5 t}$ in Eq. (3) and $\beta_{3 t}$ in Eq. (4) report whether baronies and PLU's suffering from medium, high, or medium-high blight infection, respectively, in 1845 and 1846 changed differently than baronies and PLU's with low or low-medium blight infection when there was a Loan Fund, or more Loan Fund lending, compared to the difference in changes between medium, high, or medium-high infection and low or low-medium infection baronies or PLU's when there was no Loan Fund, or less lending. In this way, the coefficients $\beta_{4 t}$ and $\beta_{5 t}$ in Eq. (3) and $\beta_{3 t}$ in Eq. (4) compare average changes in worse infected baronies or PLU's with a Loan Fund relative to less infected baronies or PLU's with a Loan Fund, versus average changes in worse infected baronies or PLU's without a Loan Fund relative to less infected baronies or PLU's without a Loan Fund.

Because it is a strong identifying assumption that the establishment of a Loan Fund was uncorrelated with other, unobservable, non-fixed baronial characteristics that might have been correlated with differential responses to blight, I estimate Eqs. (3) and (4) by two-stage least squares regression, using the presence of an Association of Irish Musical Societies (AIMS) musical society in a given barony or PLU to instrument for the presence of a Loan Fund during the famine. Because Eqs. (3) and (4) include numerous interactions with Loan Fund presence as explanatory variables, instruments are AIMS musical society presence $\left(M_{b}\right)$, as well as interactions of AIMS musical society

\footnotetext{
${ }^{36}$ Data limitations do not permit us to include pre-famine observations of farm size and livestock holdings. 
presence with blight $\left(M_{b} \times B_{b}^{\text {med }}\right.$ and $\left.M_{b} \times B_{b}^{\text {high }}\right)$, and lags of pre-famine outcomes, $\left(M_{b} \times y_{b t-n}\right)$. The first stage therefore consists of separately regressing each endogenous regressor $\left(L_{b}, L_{b} \times B_{b}^{\text {med }}\right.$, $L_{b} \times B_{b}^{h i g h}, L_{b} \times y_{b t-n}$, and $\left.B O R D_{b}\right)$ on all instruments $\left(M_{b}, M_{b} \times B_{b}^{\text {med }}, M_{b} \times B_{b}^{\text {high }}, M_{b} \times y_{b t-n}\right.$, and $B O R D_{-} M_{b}$ ) and all exogenous regressors to generate fitted values.

In the 1740s and 1750s, the Dublin Musical Society began extending small loans to poor Dubliners, and in 1756 incorporated a formal society for this purpose. Thereafter, for a brief time the Dublin Musical Society operated a loosely affiliated branch system of musical loan societies, "To receive contributions, and to lend out such sum or sums of money interest free" to poor farmers and laborers. These constituted many of the first Loan Funds, though over time numerous pawnbrokers and Mont-de-Piétés reconstituted as Loan Funds, with all such societies eventually being formally unified and lending practices standardized under the central Loan Fund Board in the 1830s (Hollis and Sweetman 1998, 2001; McLaughlin 2009). ${ }^{37}$

The inclusion and exclusion restrictions are that the presence of an AIMS musical society in a given barony or PLU is correlated with the presence of a Loan Fund in the same barony or PLU during the famine, but is otherwise uncorrelated with $\varepsilon_{b t}$ or $\varepsilon_{u t} .{ }^{38}$ Since AIMS musical societies are generally small troupes that often travel frequently for performances, it is unlikely that their presence is correlated with other unobservable variables that might have differentially affected relative adjustment to blight, for example wealth and social capital. ${ }^{39}$ Nonetheless, as a robustness check I regress AIMS musical society presence on pre-famine baronial characteristics, with results presented in Table 2. OLS-estimated coefficients presented in column 4 indicate that pre-famine baronial characteristics are poor predictors of AIMS presence. None of the estimated coefficients are statistically significant, and the fit is poor. In particular, that estimated coefficients on baronial valuation, potato crop and fourth-class housing shares are not significant suggests that musical societies were not correlated with pre-famine levels of poverty. The fact that estimated coefficients on literacy, population density, and especially religious diversity are also not significant indicates that local differences in social capital were likewise uncorrelated with AIMS presence.

37 As data is not available on musical societies by barony in the $18^{\text {th }}$ and $19^{\text {th }}$ centuries, I instead use current AIMS member societies as an instrument.

${ }^{38}$ It might be objected that the use of AIMS members would involve selection-on-outcome bias, on the basis that musical societies in worse affected baronies might have been less likely to survive the famine. This is, however, unlikely, given the class from which patrons of musical societies were typically drawn. Moreover, first-differencing eliminates omitted variable bias from unobservable fixed baronial characteristics that might be correlated with both the presence of an AIMS musical society and differential relative responses to blight.

39 Furthermore, social capital would only bias estimated effects of Loan Funds on first-differenced outcomes upward if it were non-fixed, which would mean that districts with less social capital before the famine also lost more social capital during the famine. 
Several additional estimation details are worth noting. First, regressions for livestock outcomes are subdivided by farm size to allow for average effects to differ for different types of farms. ${ }^{40}$ Second, the outcome years analyzed are selected so as to, where possible, estimate average effects one, five, ten, twenty, and forty years after the end of the famine in 1851. Where it is possible to analyze outcomes between 1845 and 1851-in other words, during the famine years-I do so. Third, to condense reported results and reduce noise for average changes in the value of livestock holdings, estimated coefficients are pooled across some later time periods. Fourth, standard errors are clustered at the baronial or PLU-level to adjust for heteroskedasticity and within-barony or within-PLU correlation over time. Fourth, to test whether observed effects were the result of microfinance lending by the Irish Loan Funds in particular or financial services more broadly, as noted above I reestimate Eqs. (3) and (4) in section 6.3 by replacing Loan Fund variables and interactions with the pre-famine number of banks.

\section{$6 \quad$ Results}

\subsection{Estimated effects of blight severity}

To illustrate the empirical framework and analysis, results from estimating Eqs. (1) and (2) are presented in Figure 4. Each panel graphs estimated coefficients $\left(\beta_{1 t}\right.$ 's and $\beta_{2 t}$ 's from Eq. (1) and $\beta_{t}$ 's from Eq. (2)) with 95\% confidence intervals, representing differences in changes in the indicated outcome variable in high and medium blight baronies or medium-high blight PLU's relative to low blight baronies or low-medium blight PLU's. ${ }^{41}$ Panels E and F graph estimated coefficients representing differences in changes in the value of buffer (swine and poultry) and grazing (cattle, sheep, and goats) livestock holdings in high and medium blight baronies relative to low blight baronies for farms under 15 acres. I find that, in the short and medium runs, increases in buffer livestock holdings constituted a major response to blight for farms of less than 15 acres. Demographic change and decreases in the percentage of farms of less than 5 acres were also significant short- to

\footnotetext{
${ }^{40}$ Farm size is subdivided at 0 to 15 acres and over 15 acres, with farms under 15 acres collectively comprising $59 \%$ of all farmholdings in 1847. Because survey data of farm size is only categorized as under 1 acre, 1 to 5 acres, 5 to 15 acres, 15 to 30 acres, or over 30 acres, finer subdivisions or median calculations are not possible. Available data do not allow us to distinguish average changes in population and crop acreage by farm size.

41 Unfortunately, multiple pre-famine observations are only available for population and potato crop share, meaning it is not possible to plot pre-famine estimated changes in the fraction of farms under 5 acres or aggregate livestock holdings.
} 
medium-run margins of adjustment. Crop diversification occurred primarily over the medium run, while relative accumulations of grazing livestock, with an implied transition from tillage to pasture, took place only in the long run.

\subsubsection{Short and medium runs}

Demographic change and related changes in patterns of landholding appear to have constituted significant short- to medium-run margins of adjustment to blight. ${ }^{42}$ Columns 1 and 2 of Table 3 report estimates of Eq. (1) for changes in total population in the indicated year, with $Y_{\text {bpre }}=Y_{b 1841}$. Estimated coefficients show that, relative to low blight baronies, baronies that were severely or considerably infected by blight in 1845 and 1846 experienced population declines that were greater by 7004.299 and 4698.786 persons between the censual years 1841 and $1851 .{ }^{43}$ A reduction in the fraction of farms under 5 acres was also a short-run result of blight. Estimates of Eq. (2) for changes in the share of total farmholdings under 5 acres at the PLU level are reported in column 6 of Table 3. The estimated coefficients indicate that the decline in the fraction of all farmholdings under 5 acres was 14.5 percentage points greater between 1845 and 1848 in medium-high blight PLU's than in low-medium blight PLU's. By the end of the famine, the under-5-acres share of all farmholdings was 8.5 percentage points lower in worse affected PLU's.

Crop substitutions were a sticky medium-run margin of adjustment, with substantial substitutions occurring only after two successive years of blight. Columns 3 through 5 of Table 3 report estimates of Eqs. (1) and (2) for changes in the potato crop's share of total tillage acreage, first differenced from the potato crop share in 1845 , i.e. $Y_{b p r e}=Y_{b 1845}$, the last crop planted before the arrival of blight. ${ }^{44}$ The estimated coefficients reported in columns 3 and 4 show that between

${ }^{42}$ Unfortunately, available data does not allow us to distinguish between changes in population owing to net outmigration versus excess mortality, though presumably the relative contributions of both causes varied with blight severity and time horizon. The cheapest transatlantic steerage fares could be had for as low as $£ 3$ or $£ 4$, which represented total annual income for almost two-thirds of the Irish population (Ó Gráda and O'Rourke 1997).

43 While general equilibrium effects cannot be discounted, historical evidence, including county-level emigration statistics, indicates that internal migration during the famine was extremely limited. This owed both to the local nature of the distribution of statutory relief, and to the numerous restrictions on rural mobility by local landlords (Cousens 1960a). In the extreme, however, if the entire population decline in severely and considerably infected baronies consisted of migration to moderately infected baronies, then estimated coefficients would be halved. But considering that for Ireland as a whole, emigration was roughly equal to excess mortality, estimated coefficients $25 \%$ smaller than those reported seem a plausible extreme lower bound, especially if more severe blight was more likely to result in death or outright emigration than within-country migration.

${ }^{44}$ These results must be treated with considerable caution, as official published statistics on potato crop acreages do not exist prior to 1847. The 1844-1846 figures used here are thus estimates compiled by the late Irish economic historian Austin Bourke from constabulary reports. See Bourke (1960, 1965b). Mokyr (1981) and Solar (1987) argue that Bourke's estimates are likely too high. However, their criticisms focus on Bourke's aggregation method and 
1845 and 1846, baronies experiencing severe and considerable blight infection increased the nonpotato crop share of total tillage acreage by 3.6 and 2.4 percentage points more than moderately impacted baronies. Columns 3 and 4 also indicate that by 1852, high and medium blight baronies had reduced the potato's share of total crop acreage by 14.8 and 11.5 percentage points more than low blight baronies.

Column 5 of Table 3 reports estimates of Eq. (2) for relative changes at the PLU level in the share of total tillage acres under potato crop after 1845. Estimated coefficients indicate that the fraction of total crop acreage allocated to potato cultivation in medium-high blight PLU's was only substantially relatively reduced after two successive potato crop failures. While PLU's suffering medium-high blight infection in 1845-46 only increased the fraction of total tillage acreage allocated to other crops in 1846 by a non-statistically significant 1.6 percentage points more than low-medium blight PLU's, by 1847 PLU's that had suffered higher infection rates in the preceding two years increased the non-potato share of total tillage acreage by a statistically significant 10.7 percentage points more than low-medium blight PLU's. Column 5 also reports that the reduction in the share of total tillage acreage under potato crop in 1848 and 1849 was 14.2 and 11.9 percentage points greater, respectively, in medium-high blight PLU's versus low-medium blight PLU's.

Changes in buffer livestock holdings of poultry and swine were a significant short- and mediumrun response to blight by farms under 15 acres. Panel A of Table 4 reports estimates of Eq. (1) for changes in the total value of poultry and swine holdings, subdivided by farm size. Unfortunately, livestock data are only available from 1847, so differenced outcomes are of changes in the value livestock holdings from levels observed during the third and worst year of the famine, and therefore reflect relative recovery and adaptation from the famine's nadir, rather than variation in outcomes during the critical $1845-47$ period..$^{45}$

In the years immediately following 1847 , farms under 15 acres in baronies experiencing severe or considerable blight infection in 1845 and 1846 substantially increased the value of holdings of buffer stocks of poultry and swine relative to farms under 15 acres in baronies experiencing only moderate

possible conflation of figures ambiguously quoted in Irish or statute acres. By keeping the data disaggregated, the first objection does not apply here. Further, my analysis focuses on relative changes in potato acreage, rather than absolute levels, which means that so long as quotation in Irish or statute acres was uncorrelated with blight severity, the choice of unit is irrelevant. Finally, the estimated coefficients on blight severity for 1846 must be considered merely indicative, as my blight severity index consists mostly of observations made in 1846.

${ }^{45}$ If livestock data were available for 1845 and 1846, we would expect to observe large sell-downs of livestock assets in 1846 and 1847, particularly by small farms. Unfortunately, available data only allow us to analyze differential responses after the worst of the famine was already over, and thus presumably reflect both rebuilding of depleted livestock holdings and expansion of precautionary buffer stocks. 
infection. Panel A, columns 1 and 2 of Table 4 report that in the year following "Black 47," farms of less than 15 acres in baronies experiencing severe or considerable infection had increased buffer stock holdings by non-statistically significant $£ 158.60$ and $£ 33.37$ more than farms of less than 15 acres in baronies experiencing only moderate infection. By the end of the famine, in 1852, farms under 15 acres in high and medium blight baronies had increased buffer stocks by $£ 486.33$ and $£ 316.01$ more, respectively, than farms under 15 acres in low blight baronies. ${ }^{46}$

In contrast, estimated coefficients reported in Panel B, columns 1 and 2 of Table 4 indicate that through 1852, relative to farms under 15 acres in low blight baronies, farms under 15 acres in high and medium blight baronies did not experience systematically different changes in the value of holdings of grazing livestock (cattle, sheep, and goats). Meanwhile, estimated coefficients reported in Panels A and B, columns 3 and 4 of Table 4 reveal that in both the short and medium runs, farms over 15 acres in high and medium blight baronies did not experience systematically different changes in either the value of buffer livestock holdings or in the value of holdings of grazing livestock, relative to farms over 15 acres in low blight baronies.

While calculated differences (not displayed) between estimated coefficients of high versus medium blight infection on changes in population and the value of buffer livestock holdings by farms under 15 acres are statistically significant to at least the level of $\alpha=0.10$, calculated differences between estimated coefficients of high versus medium infection for potato crop share are not statistically significant. This suggests that, in the short and medium runs, baronies experiencing severe versus considerable blight infection did not experience systematically different changes in crop acreage allocation, with both diversifying crop portfolios to roughly the same extent and instead responding differentially along the demographic and livestock margins.

\subsubsection{Long run}

Large relative population declines during the famine appear to have persisted at a roughly even level through the very long run. Columns 1 and 2 of Table 3 show that by 1891 the cumulative population decline in severely and considerably impacted baronies exceeded that in moderately impacted baronies by an estimated 7859.179 and 5002.676 persons, respectively. Meanwhile,

${ }^{46}$ To place these values in perspective, at $6 \mathrm{~d}$. ( $\left.£ 0.025\right)$ per chicken and $£ 1,5 \mathrm{~s} .(£ 1.10)$ per pig, this corresponds to relative increases of 19,453 and 12,640 chickens (17.56 and 12.32 per 1852 farm) or 389 and 253 pigs (0.35 and 0.25 per 1852 farm) for farms under 15 acres in high and medium blight baronies, relative to farms under 15 acres in low blight baronies. 
differential relative changes in farm size distribution during the famine appear to have dissipated over the long run. Estimated coefficients reported in column 6 of Table 3 show that though the relative decline in the proportion of farmholdings under 5 acres remained larger through 1871 in PLU's suffering medium-high blight infection relative to PLU's suffering low-medium blight infection, beyond 1856 none of the estimated coefficients are statistically significant.

Crop substitutions during and immediately after the famine persisted through the long run, though reconverged slightly from a peak gap in 1848 (at the PLU level), which suggests initial overshooting. Estimated coefficients reported in columns 3 and 4 of Table 3 show that after peaking in 1856 (at the baronial level), the cumulative reduction in the share of acreage under potato crop was still 15.7 and 12.3 percentage points greater in severely and considerably impacted baronies in 1871 than in moderately impacted baronies. At the PLU level, estimated coefficients reported in column 5 of Table 3 reveal that as late as 1891 the cumulative reduction in the share of acreage under potato crop was still 11.3 percentage points larger in PLU's suffering medium-high blight infection, relative to low-medium blight PLU's.

Results reported in Panel A, columns 1 and 2 of Table 4 reveal that relative increases in buffer livestock holdings of swine and poultry remained an important margin of adjustment through the long run for farms under 15 acres in high blight baronies, but not for farms under 15 acres in medium blight baronies. While the increase in the value of buffer livestock holdings by farms under 15 acres in high blight baronies, relative to farms under 15 acres in low blight baronies, peaked in 1852 , in 1866-71 the cumulative increase in buffer livestock holdings was still $£ 441.11$ greater by farms under 15 acres in high blight baronies relative to farms under 15 acres in low blight baronies. In contrast, relative increases in buffer livestock holdings by farms under 15 acres in medium blight baronies appear to have dissipated after 1852 .

Results reported in Panel B, columns 1 and 2 of Table 4 reveal that relative increases in the value of grazing livestock holdings of cattle, sheep, and goats were also a significant margin of adjustment over the long run for farms under 15 acres in high blight baronies, but not for farms under 15 acres in medium blight baronies. In 1856-61, farms under 15 acres in high blight baronies had increased holdings of grazing livestock by $£ 2185.90$ more than farms under 15 acres in low blight baronies, with the relative gap persisting through 1871. Estimated coefficients reported in Panels A and B, columns 3 and 4 of Table 4, however, indicate that over the long run, farms over 15 acres in high and medium blight baronies did not experience systematically different changes in either the 
value of buffer livestock holdings or in the value of holdings of grazing livestock, relative to farms over 15 acres in low blight baronies.

While calculated differences (not displayed) between estimated coefficients of high versus medium blight infection on changes in population and the values of buffer and grazing livestock holdings are statistically significant to at least the level of $\alpha=0.10$, calculated differences in estimated coefficients of high versus medium blight infection on changes in potato crop share are not. This suggests that, in the long run, baronies experiencing considerable versus severe blight infection did not experience systematically different changes in crop acreage allocation, but instead responded differentially by converting acreage from tillage to pasture and maintaining larger buffer assets. Beyond moderate blight infection, baronies more severely infected therefore diversified crop portfolios to roughly the same extent, with differential adjustments occurring instead through more fundamental changes in land use; namely, the transition from tillage to pasture.

In sum, results reported in sections 6.1.1 and 6.1.2 show that population decline and accumulations of buffer livestock assets by small- to medium-sized farms of up to 15 acres constituted the primary short- and medium-run margins of adjustment to blight, whereas the primary longer-run margins of adjustment were substantial and permanent substitutions away from potato cultivation toward other tillage crops and, for farms under 15 acres in high blight baronies especially, grazing livestock. Farms over 15 acres in high and medium blight baronies, on the other hand, do not appear to have experienced systematically different changes in either the value of buffer livestock holdings or in the value of holdings of grazing livestock, in either the short or the long run, relative to farms over 15 acres in low blight baronies.

\subsection{Estimated effects of Loan Funds}

Results presented in Tables 5 and 8 reveal that Loan Funds were strongly correlated with nondemographic adjustment to blight. In particular, in the presence of a Loan Fund and/or greater Loan Fund lending, relative crop diversification, short-run relative accumulations of buffer livestock holdings, and medium-run relative substitutions toward pasture were greater where the magnitude of the environmental shock was greater. First-stage estimates of Loan Fund presence or average annual lending and Loan Fund presence or average annual lending interacted with blight severity, 
instrumented for by AIMS musical society presence and AIMS musical society presence interacted with blight severity, are reported in Table 7.

2SLS estimated coefficients in Panel A, columns 1 and 2 of Table 5 show that the population decline between 1841 and 1851, relative to low blight baronies, was smaller by 3660.500 and 3460.445 persons in high and medium blight baronies with a Loan Fund versus high and medium blight baronies without. Loan Funds were also associated with smaller relative population declines at the intensive margin. Estimated coefficients reported in Panel B, columns 1 and 2 of Table 5 show that, relative to low blight baronies, high and medium blight baronies with $£ 1$ more in average annual Loan Fund lending from 1845 to 1850 experienced relative population declines that were smaller by 1.659 and 1.245 persons by 1851 than high and medium blight baronies without. Results presented in column 6 of Table 5 indicate that Loan Funds were also associated with smaller relative declines in the share of all farmholdings measuring under 5 acres. By 1852, relative to low-medium blight PLU's, the decline in the under-5 acres share of all farmholdings was 11.4 percentage points larger in medium-high blight PLU's without a Loan Fund versus in those with a Loan Fund.

Loan Fund lending was strongly associated with larger and more rapid relative crop portfolio diversification. 2SLS estimated coefficients reported in Panel A, columns 3 and 4 of Table 5 show that after the first year of blight, high and medium blight baronies with an active Loan Fund during the preceding year experienced relative increases in the non-potato crop share of total tillage acreage that were 6.6 and 6.2 percentage points greater, respectively, than in severely or considerably infected baronies without a Loan Fund. By the end of the famine, relative increases in the nonpotato crop share were 29.3 and 28.2 percentage points greater in severely and considerably infected baronies with a Loan Fund versus those without. 2SLS estimated coefficients reported in Panel B, column 3 of Table 5 likewise reveal that at the intensive margin, relative to low blight baronies, high blight baronies with $£ 1000$ more in Loan Fund lending in 1845 increased acreage allocated to other crops in 1846 by 1-percentage point more than high blight baronies without. Estimated coefficients reported in Panel B, columns 3 and 4 show that by 1852, relative to low blight baronies, high and medium blight baronies with $£ 1000$ more in average annual Loan Fund lending during the famine had increased the fraction of acreage allocated to other crops by 9 and 6 percentage points more, respectively, than high and medium blight baronies without.

2SLS estimates of Eq. (4) at the PLU level, reported in Panel A, column 5 of Table 5 indicate that Loan Fund activity had a very large effect on crop acreage reallocation during the famine years, 
particularly following two successive crop failures. After an 11.4-percentage point larger relative decline in the potato crop's share of total acreage under tillage crop in 1846, in 1847 medium-high blight PLU's with a Loan Fund had, relative to low-medium blight PLU's, reduced the potato's share of total crop acreage by an estimated 39.4 percentage points more than medium-high blight PLU's without a fund. By 1852, relative to low-medium blight PLU's, medium-high blight PLU's with a Loan Fund had relatively reduced the fraction of total tillage acreage under potato crop by 34.6 percentage points.

Estimated coefficients for the main effects of medium and high blight infection $\left(\beta_{1 t}\right.$ 's and $\beta_{2 t}$ 's from Eq. (3) and $\beta_{t}$ 's from Eq. (4)) on average changes in population, crop acreage, and farmholdings are reported in Table 6 . Results indicate that the main effects of more severe blight infection remain large and statistically significant even after controlling for the main and interactive effects of differential access to Loan Fund credit.

2SLS estimated coefficients reported in Panel A, columns 1 and 2 of Table 8 indicate that Loan Funds also had significant effects on relative changes in buffer livestock holdings by farms under 15 acres. By 1848, relative to farms under 15 acres in low blight baronies, farms under 15 acres in high and medium blight baronies with a Loan Fund had increased the value of buffer livestock holdings by $£ 193.21$ and $£ 157.11$ more, respectively, than farms under 15 acres in high and medium blight baronies without a fund. By the end of the famine, in 1852, relative to farms under 15 acres in low blight baronies, farms under 15 acres in high and medium blight baronies with a Loan Fund had increased the value of buffer livestock holdings by $£ 673.23$ and $£ 532.62$ more, respectively, than farms under 15 acres in high and medium blight baronies without a fund. ${ }^{47}$

While Loan Funds generally do not appear to have been associated with short-run relative accumulations of grazing stock by farms under 15 acres in high and medium blight baronies, 2SLS estimated coefficients reported in Panel B, columns 1 and 2 of Table 8 indicate they were associated with greater medium-run substitutions toward pasture. By 1856, relative to farms under 15 acres in low blight baronies, farms under 15 acres in high and medium blight baronies with a Loan Fund had increased the value of grazing livestock by $£ 3486.40$ and $£ 3049.08$ more, respectively, than farms under 15 acres in high and medium blight baronies without a fund.

47 To place these values in perspective, this corresponds to relative increases of 26,929 and 21,305 chickens (24.3 and 20.77 per 1852 farm) or 539 and 426 pigs ( 0.49 and 0.42 per 1852 farm) for farms under 15 acres in high and medium blight baronies, relative to farms under 15 acres in low blight baronies. 
In contrast to farms under 15 acres, 2SLS estimated coefficients reported in Panels A and B, columns 3 and 4 of Table 8 reveal that farms over 15 acres in high and medium blight baronies with a Loan Fund generally did not experience systematically different relative increases in either buffer or grazing livestock holdings compared to farms over 15 acres in high and medium blight baronies without a Loan Fund. In fact, it appears that Loan Fund presence during the famine may actually have been associated with reductions in buffer livestock holdings by farms over 15 acres in high and medium blight baronies, relative to farms over 15 acres in low blight baronies.

Estimated coefficients for the main effects of medium and high blight infection $\left(\beta_{1 t}\right.$ 's and $\beta_{2 t}$ 's from Eq. (3)) on average changes in buffer and grazing livestock holdings by farm size are reported in Table 9. Results indicate that the main effects of more severe blight infection remain large and statistically significant even after controlling for the main and interactive effects of differential access to Loan Fund credit.

In sum, results reported in section 6.2 show that relative population declines were significantly smaller in worse affected baronies with a Loan Fund versus in those without. Loan Fund lending in worse affected districts was associated both with earlier relative crop substitutions away from the potato and the relative accumulation of buffer livestock holdings during and immediately after the famine. Medium-run adaptation through relative increases in holdings of grazing livestock by farms under 15 acres was also greater in worse affected baronies with a Loan Fund. Results additionally show that farms larger than 15 acres in worse affected baronies with a Loan Fund did not experience larger relative increases in either buffer or grazing livestock holdings, in either the short or medium runs, than farms over 15 acres in worse affected baronies without a fund. This suggests that observed differences in relative changes are primarily being driven by the effects of Loan Fund lending on smaller farms, consistent with the microfinance model of targeting lower-income households.

\subsection{Banks}

As a falsification exercise to explore whether observed differences in relative changes were the result of Loan Fund microlending in particular or the presence of financial services, and potential unobservable correlates - for example a larger depositor base-more generally, I re-estimate Eqs. (3) and (4) using the number of banks in 1843. Estimated coefficients reported in columns 1 and 2 of 
Table 10 show that the presence of an additional bank appears to have had no effect on differential relative demographic changes due to blight. High and medium blight baronies with an additional bank experienced no statistically significant differences in relative population declines versus those without. Banks may have had a short-run effect on relative changes in average farm size, with estimated coefficients reported in column 6 of Table 10 showing that by 1848 the relative decline in the share of all farmholdings under 5 acres was 4.4 percentage points larger in medium-high impact PLU's with one more bank, versus those without. But by 1852 the estimated effect dissipates entirely, suggesting that banks had no long-run impact on relative changes in farm size dispersion in areas worse affected by blight.

Estimated coefficients reported in columns 3 through 5 of Table 10 likewise reveal that the presence of an additional bank had no effect on differential relative changes in tillage acreage allocated to the potato in worse infected baronies and PLU's versus in those without an additional bank. Estimated coefficients reported in columns 7 through 14 additionally indicate that banks had no short-run effect on relative changes in either buffer or grazing livestock holdings, either by farms under 15 acres or by farms over 15 acres, in baronies worse affected by blight. Estimated coefficients reported in columns 8, 9, and 12 of Table 10 do suggest that the presence of an additional bank in high and medium blight baronies may have had a differential effect on relative changes in livestock holdings by 1856, but the sign of the effect is ambiguous, with banks appearing to have had opposite relative effects in high versus medium blight baronies.

\subsection{Additional robustness checks}

In Section 4, above, I showed that pre-famine baronial and PLU characteristics were poor predictors of blight severity and Loan Fund presence and lending. As an additional robustness check, I also estimate Eqs. (1) and (3) for average changes in outcome variables before the famine, in order to check whether pre-trends differed systematically in high and medium blight baronies versus low blight baronies, or if pre-trends differed systematically in high and medium blight baronies with a Loan Fund versus high and medium blight baronies without, relative to low blight baronies. Unfortunately, since farm size data is not available before 1845 and livestock data is not available before 1847 , it is only possible to analyze pre-trends in average changes in population from 1821 to 1831 and 1831 to 1841 , and potato crop share from 1844 to 1845 . Results are presented in Table 9 . 
Estimated coefficients reported in Panel A, columns 1 and 2 of Table 11 reveal that, relative to baronies suffering low blight infection in 1845 and 1846, baronies suffering high or medium infection had not experienced systematically different changes in population before the arrival of blight. Estimated coefficients reported in Panel A, columns 3 and 4 similarly show that relative to low blight baronies, baronies suffering high or medium infection had not experienced systematically different changes in acreage allocation to the potato; the average change in potato crop acreage as a fraction of all acres under tillage between 1844 and 1845 was statistically no different in high and medium blight baronies versus low blight baronies.

2SLS estimated coefficients reported in Panel B, columns 1 and 2 of Table 11 show that, relative to baronies suffering low blight infection in 1845 and 1846, high and medium blight baronies with a Loan Fund had not experienced systematically different pre-blight changes in population than high and medium blight baronies without a Fund. Likewise, estimated coefficients reported in Panel B, columns 3 and 4 show that, relative to low blight baronies, high and medium blight baronies with a Loan Fund had not experienced systematically different changes in acreage allocation to the potato versus high and medium blight baronies without; the average relative change in potato crop acreage as a fraction of all acres under tillage between 1844 and 1845 was statistically no different in high and medium blight baronies with a Loan Fund than in those without.

\section{$7 \quad$ Conclusion}

The Great Famine was a devastating event that had profound and persistent effects on Irish population and agriculture. Initial short- to medium-run responses to blight, in the form of greater accumulations of buffer livestock assets and demographic decline, were eventually superceded in the medium and long runs by changes in land use, namely, substitutions away from the potato toward other tillage crops and pasture. Thus, while proto capital markets and labor were much more flexible in the short and medium runs, land was for the most part initially fixed, with fundamental changes in land use only occurring over the long run. Access to microcredit from the Irish Loan Funds was an important factor in enabling non-demographic adjustment to the adverse environmental shock.

In the short to medium run, districts that were severely or considerably afflicted by blight in the first two years of the famine experienced larger population declines than moderately affected districts, with consistent gaps persisting even 40 years after the famine. By the end of the famine, 
the fraction of all farmholdings under 5 acres had declined by 8.5 percentage points more in worse affected districts. Blight furthermore immediately affected patterns of livestock holding. In the short and medium runs, relative to small farms under 15 acres in moderately impacted districts, small farms in districts suffering severe or considerable blight infection in 1845 and 1846 significantly increased stocks of chickens and pigs - traditional income buffers in the event of crop failure.

In the medium to long runs, however, worse affected districts effected larger substitutions toward other tillage crops and grazing livestock. Relative to lesser impacted districts, districts that were worse affected by blight substantially and permanently converted acreage under potato cultivation to other crops, though did so only after two successive potato crop failures. In the long run, the potato's share of total tillage acreage declined by 15.7 and 12.3 percentage points more in severely and considerably districts than in moderately impacted districts. Acreage reallocation to pasture by farms under 15 acres was also a significant long-run margin of adjustment, with farms under 15 acres in severely affected districts increasing holdings of grazing stocks of cattle, sheep and goats, relative to farms under 15 acres in moderately affected districts.

Microfinance credit from the Irish Loan Funds played a significant role in non-demographic adjustment to blight. The presence of at least one Loan Fund in a severely affected district during the famine was associated with a 3661-person smaller relative population decline by 1851. Loan Fund lending in worse affected districts was associated both with earlier relative crop substitutions away from the potato and the relative accumulation of larger buffer livestock holdings during and immediately after the famine. Specifically, by 1847, the worst year of the famine, more severely infected districts with a Loan Fund had reduced the fraction of total tillage acreage under potato crop by 39.4-percentage points more than more severely infected districts without a fund, relative to less infected districts. Similarly, by 1852, farms under 15 acres in severely and considerably infected districts with a Loan Fund had increased stocks of pigs and poultry by $£ 673.23$ and $£ 532.62$ more than farms under 15 acres in severely and considerably infected districts without a fund, relative to farms under 15 acres in moderately infected districts. Medium-run adaptation through relative increases in holdings of grazing livestock of cattle, sheep, and goats by farms under 15 acres was also greater in worse affected districts with a Loan Fund.

The results of this study therefore suggest that access to microfinance plays a significant role in short- and medium-run non-demographic adjustment to adverse environmental shocks in a subsistence or near-subsistence economy. Longer-run, non-demographic adaptations to the arrival of 
blight in Ireland-specifically, relative crop portfolio diversification and substitutions away from tillage toward pasture-were effected earlier and to a greater extent in worse affected districts with a microfinance lender versus in those without. Moreover, access to microcredit appears to have allowed farmers to acquire stocks of relatively cheap, liquid buffer livestock assets with low, but also low volatility, yields. In particular, the relative accumulation of stocks of poultry and swine by small farms in worse affected districts with a microfinance fund versus in those without suggests that the importance of certain types of buffer livestock may largely reside in their ability to provide a relatively cheap hedge against adverse harvest shocks by yielding a low but relatively reliable supplemental income stream, for example through the sale of eggs from poultry stocks. This contrasts with more conventional buffer stock models, which emphasize liquidation value. Future research should perhaps therefore focus somewhat less attention on changes in net livestock sales in response to adverse production shocks, and somewhat more attention on changes in the contribution of net revenues from different types of livestock production to total household net revenue.

Lastly, since the results presented in this paper indicate that substitutions away from the potato, a highly non-tradeable good, toward the production of more tradeable goods-wheat, oats, eggs, pork, butter, and beef-constituted a critical margin of adjustment, further research is needed to elucidate the linkages between local, national, and international markets during the famine. In addition, short-run relative accumulations of buffer livestock by smaller Irish farms in worse affected districts with a microfinance fund simultaneously with possible relative drawdowns of such stocks by larger farms point toward the potential role of markets for livestock assets among farms of different scales in smoothing adjustment to adverse production shocks. Evidence of relative changes in average farm size similarly indicates that further research is needed to elucidate markets for land during and after the famine, and in particular the mechanisms of land transfer from smaller to larger farms, and possibly related changes in population and agricultural labor force structure. 


\section{References}

Besley, T. and A. Case. 1993. "Modelling Technology Adoption in Developing Countries." American Economic Review Papers and Proceedings, Vol. 83, No. 2, pp. 396-402.

Bourke, A. 1960. "The Extent of the Potato Crop in Ireland at the Time of the famine." Journal of the Statistical and Social Inquiry Society of Ireland, Vol. 20, No. 3, pp. 1-35.

Bourke, A. 1965a. "The Agricultural Statistics of the 1841 Census of Ireland. A Critical Review." Economic History Review, Vol. 18, No. 2, pp. 376-391.

Bourke, A. 1965b. "The Potato, Blight, Weather and the Irish Famine." Ph.D. Thesis, National University of Ireland.

Bourke, A. 1993. The Visitation of God? The Potato and the Great Irish Famine. Dublin: Lilliput.

Campbell, D. 1984. "Response to Drought among Farmers and Herders in Southern Kajiado District, Kenya." Human Ecology, Vol. 12, No. 1, pp. 35-64.

Clarkson, L. et al. 1997. Database of Irish Historical Statistics. Colchester, Essex: UK Data Archive [distributor], November 1997. SN: 3578.

Cousens, S. 1960a. "The Regional Pattern of Emigration during the Great Irish Famine, 1846-51." Institute of British Geographers Transactions and Papers, No. 28, pp. 119-134.

Cousens, S. 1960b. "Regional Death Rates in Ireland during the Great Famine, from 1846 to 1851." Population Studies, Vol. 14, No. 1, pp. 55-74.

Cousens, S. 1962. "The Regional Variation in Mortality during the Great Irish Famine." Proceedings of the Royal Irish Academy, Vol. 63, pp. 127-149.

Cousens, S. 1964. “The Regional Variations in Population Changes in Ireland, 1861-1881" Economic History Review, Vol. 17, No. 2, pp. 301-321.

Davidson, W. 1933. "History of Potato Varieties." Journal of the Department of Agriculature, Eire, Vol. 33, pp. 57-81.

de Janvry, A., M. Fafchamps, and E. Sadoulet. 1991. "Peasant Household Behavior with Missing Markets: Some Paradoxes Explained.” Economic Journal, Vol. 101, No. 409, pp. 1400- 1417.

Dell, M., B. Jones, and B. Olken. 2012. "Temperature Shocks and Economic Growth: Evidence from the Last Half Century." American Economic Journal: Macroeconomics, Vol. 4, No. 3, pp. 66-95.

Dercon, S. 1996. "Risk, Crop Choice, and Savings: Evidence from Tanzania." Economic Development and Cultural Change, Vol. 44, No. 3, pp. 485-513.

Dercon, S., 2002. "Income Risk, Coping Strategies, and Safety Nets." The World Bank Research Observer, Vol. 17, No. 2, pp. 141-166.

Deschenes, O. and M. Greenstone. 2007. "The Economic Impacts of Climate Change: Evidence from Agricultural Output and Random Fluctuations in Weather." American Economic Review, Vol. 97, No. 1, pp. 354-385. 
Dufferin, F.T.B. and G.F. Boyle. 1847. Narrative of a Journey from Oxford to Skibbereen during the Year of the Irish Famine. Oxford: John Henry Parker.

Duflo E., M. Kremer, and J. Robinson. 2008. "How High Are Rates of Return to Fertilizer? Evidence from Field Experiments in Kenya." American Economic Review Papers and Proceedings, Vol. 98, No. 2, pp. 482-488.

Fafchamps, M., C. Udry, K. Czukas. 1998. "Drought and Saving in West Africa: Are Livestock a Buffer Stock?” Journal of Development Economics, Vol. 55, No. 2, pp. 273-305.

Feder, G. 1980. "Farm Size, Risk Aversion and the Adoption of New Technology under Uncertainty." Oxford Economic Papers, Vol. 32, No. 2, pp. 263-283.

Foster, A., and M. Rosenzweig. 1995. "Learning by Doing and Learning from Others: Human Capital and Technical Change in Agriculture." Journal of Political Economy, Vol. 103, No. 6, pp. 1176-1209.

Foster, A. and M. Rosenzwieg. 2010. "Microeconomics of Technology Adoption." Yale University Economic Growth Center Discussion Paper No. 984.

Gine, X. and S. Klonner. 2005. "Credit Constraints as a Barrier to Technology Adoption by the Poor: Lessons from South Indian Small-scale Fishery." World Bank Policy Research Working Paper 3665 .

Goodspeed, T. 2014. "Microcredit and Adjustment to Environmental Shock: Evidence from the Great Famine in Ireland." Mimeo.

Goodspeed, T. 2015. "Environmental Shocks and Sustainability in Microfinance: Evidence from the Great Famine of Ireland." Mimeo.

Hansard, T. 1846. Hansard's Paliamentary Debates, vol. 88. London: G. Woodfall and Son, 1846.

Hollis, A. and A. Sweetman. 1998. "Microcredit in Prefamine Ireland." Explorations in Economic History, Vol. 35, No. 4, pp. 347-380.

Hollis, A. and A. Sweetman. 2001. "The Life-Cycle of a Microfinance Institution: An Economic Analysis of the Irish Loan Funds," Journal of Economic Behavior and Organization, Vol. 34, No. 3, pp. 291-311.

Hollis, A. and A. Sweetman. 2004. "Microfinance and Famine: The Irish Loan Funds during the Great Famine.” World Development, Vol. 32, No. 9, pp. 1509-1523.

Hornbeck, R. 2012. "The Enduring Impact of the American Dust Bowl: Short- and Long-run Adjustments to Environmental Catastrophe." American Economic Review, Vol. 102, No. 4, pp. 14771507 .

Jayachandran, S. 2006. "Selling Labor Low: Wage Responses to Productivity Shocks in Developing Countries.” Journal of Political Economy. Vol. 114, No. 3, pp. 538-575.

Kazianga, H. and C. Udry. 2006. "Consumption Smoothing? Livestock, Insurance and Drought in Rural Burkina Faso." Journal of Development Economics, Vol. 79, No. 2, pp. 413-446. 
Kinnan, C. and R. Townsend. 2012. "Kinship and Financial Networks, Formal Financial Access and Risk Reduction.” American Economic Review, Vol. 102, No. 3, pp. 289-293.

Koepsell, P. and J. Pscheidt. 1994. Pacific Northwest Plant Disease Control Handbook, Corvallis: Oregon State University Press.

McGregor, P. 1984. "The Impact of the Blight upon the Pre-Famine Rural Economy in Ireland." Economic and Social Review, Vol. 15, No. 4, pp. 289-303.

McLaughlin, E. 2009. "Microfinance Institutions in Nineteenth Century Ireland." Ph.D. Thesis, National University of Ireland.

Mokyr, J. 1985. Why Ireland Starved: A Quantitative and Analytical History of the Irish Economy, 1800-1850. London: Allen and Unwin.

Munshi, K. 2004. "Social Learning in a Heterogeneous Population: Technology Diffusion in the Indian Green Revolution.” Journal of Development Economics, Vol. 73, pp. 185- 213.

Ó Gráda, C. 1995. The Great Irish Famine. Cambridge: Cambridge University Press.

Ó Gráda, C. 1999. Black '47 and Beyond: The Great Irish Famine in History, Economy, and Memory. Princeton: Princeton University Press.

Ó Gráda, C. 2008. “The Early History of Irish Savings Banks," UCD Centre for Economic Research Working Paper Series.

Ó Gráda, C. and K. O’Rourke. 1997. “Migration as Disaster Relief: Lessons from the Great Irish Famine." European Review of Economic History, Vol. 1, No. 10, pp. 3-25.

Piesse, C. 1841. Sketch of the Loan Fund System in Ireland and Instructions for the Formation of a New Society. Dublin: Alexander Thom.

Reardon, T., C. Delgado and P. Matlon. 1992. "Determinants and Effects of Income Diversification Amongst Farm Households in Burkina Faso." Journal of Development Studies, Vol. 28, No. 2, pp. 264-296.

Rosen, S. 1999. "Potato Paradoxes.” Journal of Political Economy, Vol. 107, No. S6, pp. S294-S313.

Rosenzweig, M. and O. Stark. 1989. "Consumption Smoothing, Migration, and Marriage: Evidence from Rural India.” Journal of Political Economy, Vol. 97, No. 4, pp. 905-926.

Rosenzweig, M. and K. Wolpin. 1993. "Credit Market Constraints, Consumption Smoothing, and the Accumulation of Durable Production Assets in Low-Income Countries: Investments in Bullocks in India." Journal of Political Economy, Vol. 101, No. 2, pp. 223-244.

Solar, P. 1989. "The Great Famine Was No Ordinary Subsistence Crisis," in E. Margaret Crawford, ed., Famine: The Irish Experience, pp. 112-133. Edinburgh: John Donald.

Thom, A. 1850. Thom's Irish Almanac and Official Directory. Dublin: Alexander Thom.

Townsend, R. 1994. "Risk and Insurance in Village India." Econometrica, Vol. 62, No. 3, pp. 539-591. 
Udry, C. 1994. "Risk and Insurance in a Rural Credit Market: An Empirical Investigation in Northern Nigeria." Review of Economic Studies, Vol. 61, No. 3, pp. 495-526.

Verpoorten, M. 2009. "Household Coping in War and Peacetime: Cattle Sales in Rwanda. Journal of Development Economics, Vol. 88, No. 1, pp. 67-86.

World Bank. 2009. World Development Report 2010: Development and Climate Change. Washington, D.C.: World Bank.

Zwankhuizen, M., F. Govers, and C. Zadoks. 1998. "Development of Potato Late Blight Epidemics: Disease Foci, Disease Gradients, and Infection Sources.” Phytopathology, Vol. 88, No. 8, pp. 754763. 


\section{Appendix A: Data Sources}

Blight Severity: Blight severity in 1845 and 1846 is obtained from the famine Relief Commission Papers, 1845-1847. RFLC3/2, Incoming Letters: Baronial Sub-series. The National Archives of Ireland, Dublin Ireland. Observations made at the civil parish, township, or PLU level are assigned to their corresponding baronies.

Population: Population data are from the decennial Census of Ireland, 1821-1891. After 1891, data are no longer available at the baronial level. For full documentation and digitized data, see Clarkson, L.A. et al., Database of Irish Historical Statistics: Population, 1821-1911 [computer file]. Colchester, Essex: UK Data Archive [distributor], November 1997. SN: 3578, http://dx.doi.org/10.5255/UKDASN-3578-1.

Loan Funds: Data on Loan Fund activity are from the annual reports of the Loan Fund Board of Ireland, 1843-1851, compiled by Aidan Hollis and Arthur Sweetman (see Hollis and Sweetman 1998, 2001, 2004). Association of Irish Musical Societies member societies are assigned to the barony in which they are based.

Agricultural Data: Livestock and baronial-level crop data are from Returns of Agricultural Produce in Ireland (1847-1856) and Agricultural Statistics of Ireland (1857-1871). Potato crop acreages for 1844-1846 are from tabulated constabulary returns in the Public Record Office of Ireland assembled by Austin Bourke (see Bourke 1960, 1965b). Subsequent crop acreage data are from Returns of Agricultural Produce in Ireland (1847-1856) and Agricultural Statistics of Ireland (1857-1871). For full documentation and digitized data for post-1847, see Clarkson, L.A. et al., Database of Irish Historical Statistics: Agricultural Statistics Crops and Stocks, 1847-1911 [computer file]. Colchester, Essex: UK Data Archive [distributor], November 1997. SN: 3575, http://dx.doi.org/10.5255/UKDASN-3575-1. Landholding data at the Poor Law Union level is from the 1845 Appendix to the Minutes of Evidence taken before Her Majesty's Commissioners of Inquiry into the State of the Law and Practice in Respect to the Occupation of Land in Ireland. Minutes of Evidence were the official report of the Devon Commission appointed by the government of Sir Robert Peel to research landholding in Ireland. The commission was headed William Courtney, the 10th Earl of Devon. 1879 Potato yield data for 1879 is from the preliminary Parliamentary report of the 1879 Returns of Agricultural Produce in Ireland. Livestock prices are compiled from Alexander Thom's Statistics of Ireland, from Thom's Irish Almanac and Official Directory, an annual almanac of Irish statistics.

Control Variables: Adult literacy and fourth-class housing share at the baronial level and barony and PLU area in statute acres are taken from the 1841 Census of Ireland. Pre-Famine baronial and PLU valuations are from partial returns from Griffith's Valuation of Ireland, which was commissioned by the British government in preparation for the first Ordnance Survey, and Her Majesty's Poor Law Commissioners, as collected by Poor Law administrators in Ireland and presented in the 1845 Appendix to the Minutes of Evidence taken before Her Majesty's Commissioners of Inquiry into the State of the Law and Practice in Respect to the Occupation of Land in Ireland.

Climate Data: Average July humidity levels and air and soil temperatures for robustness checks are from Met Éireann, the Irish National Meteorological Service. 
Figure 1: Sample Relief Commission Report

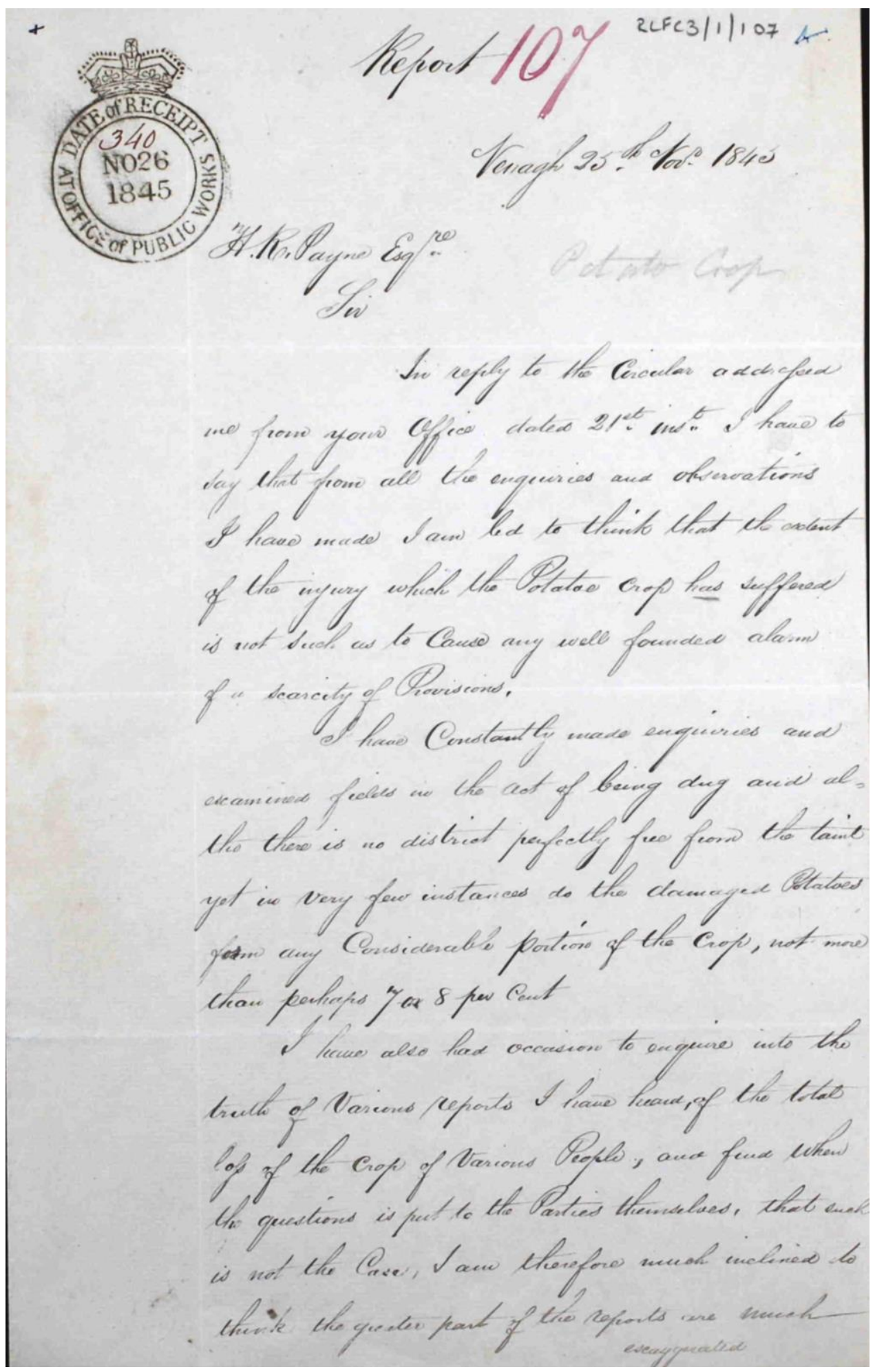

Notes: Extract from report of A.K. Crawford, Office of Public Works Surveyor, Barony of Ormond Upper, Poor Law Union Nenagh, County Tipperary, 25 November 1845. Ormond Upper was designated a "low" blight barony. 
Figure 2: Geographic Distribution of Blight Severity

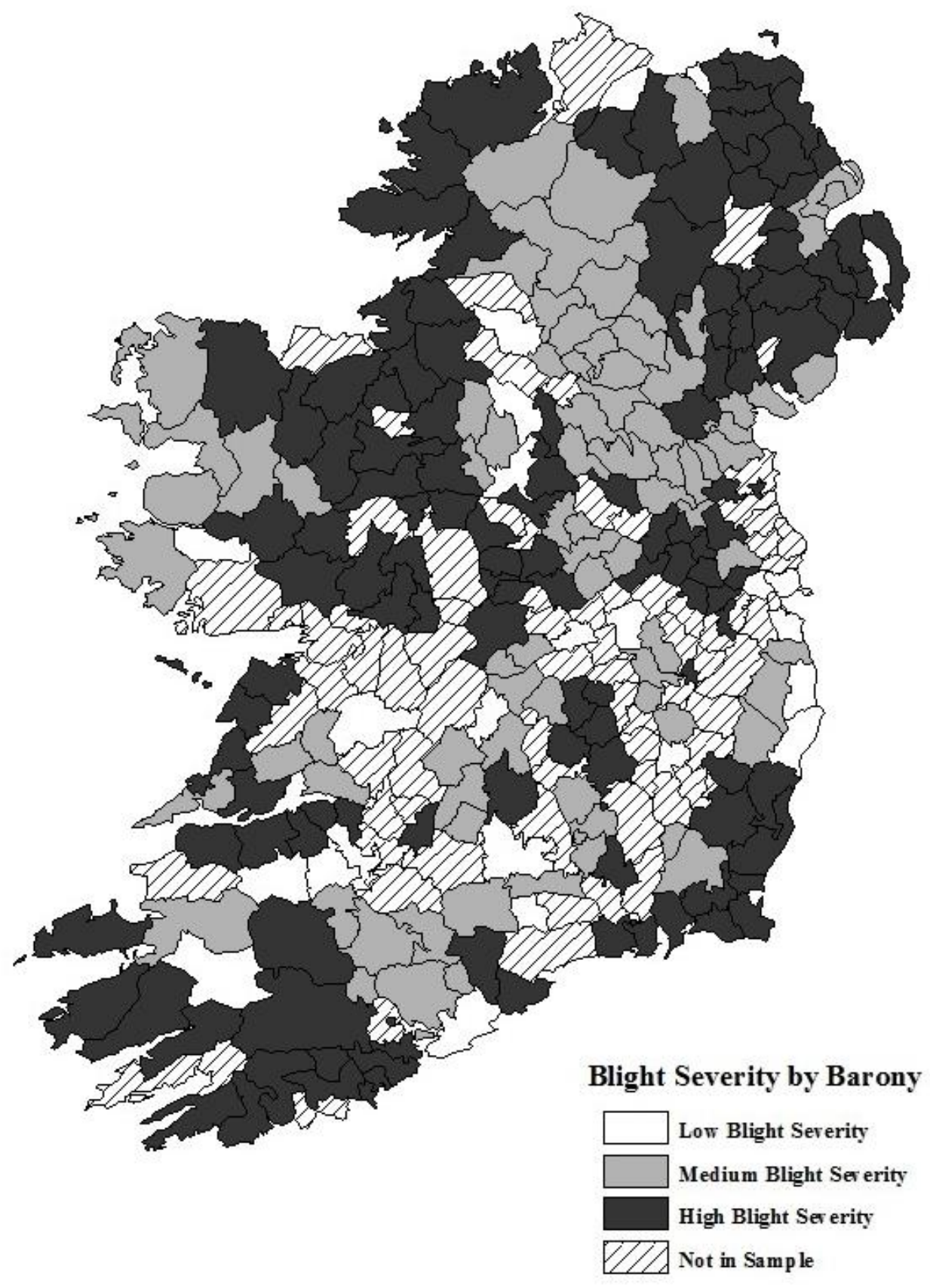


Figure 3: 1845-46 Blight Severity vs. 1879 Potato Yields

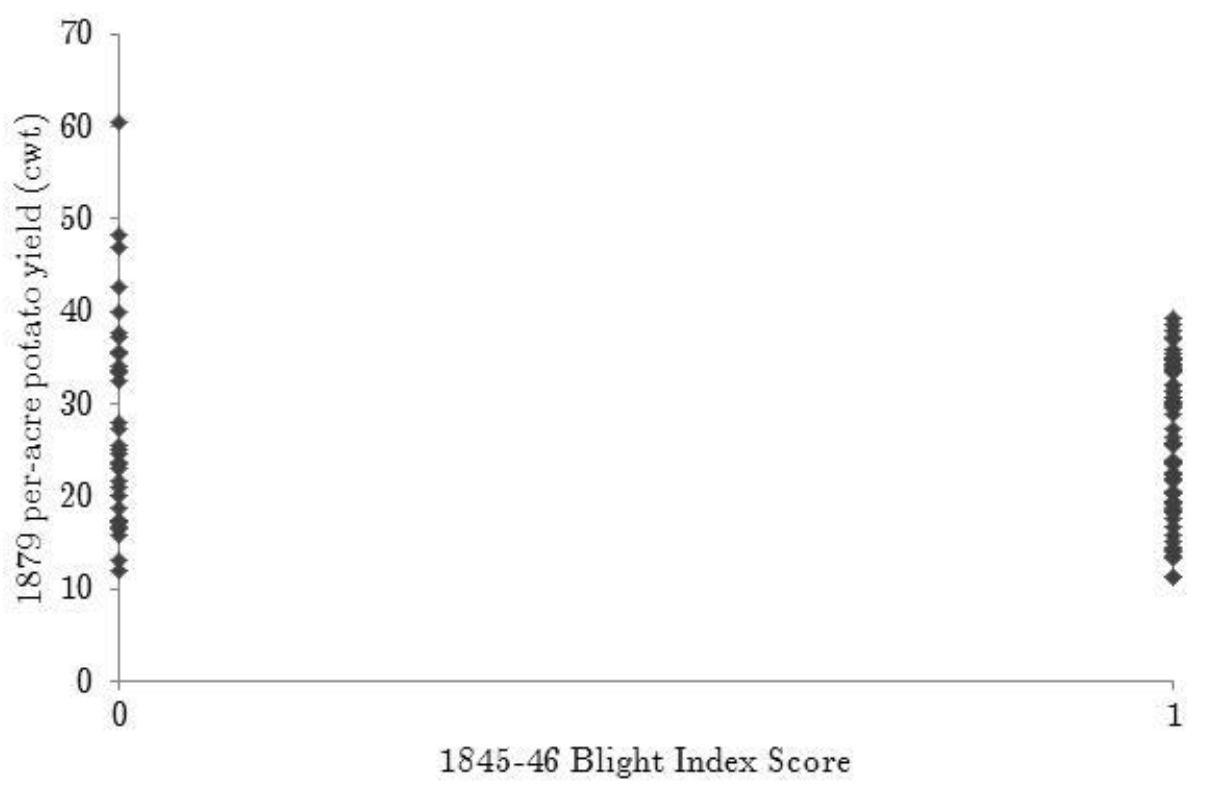

Notes: Figure 4 plots per-acre potato yields (in hundredweights) in 1879 by blight severity in 1845 and 1846 at the PLU level. 
Figure 4: Estimated Changes by Blight Severity
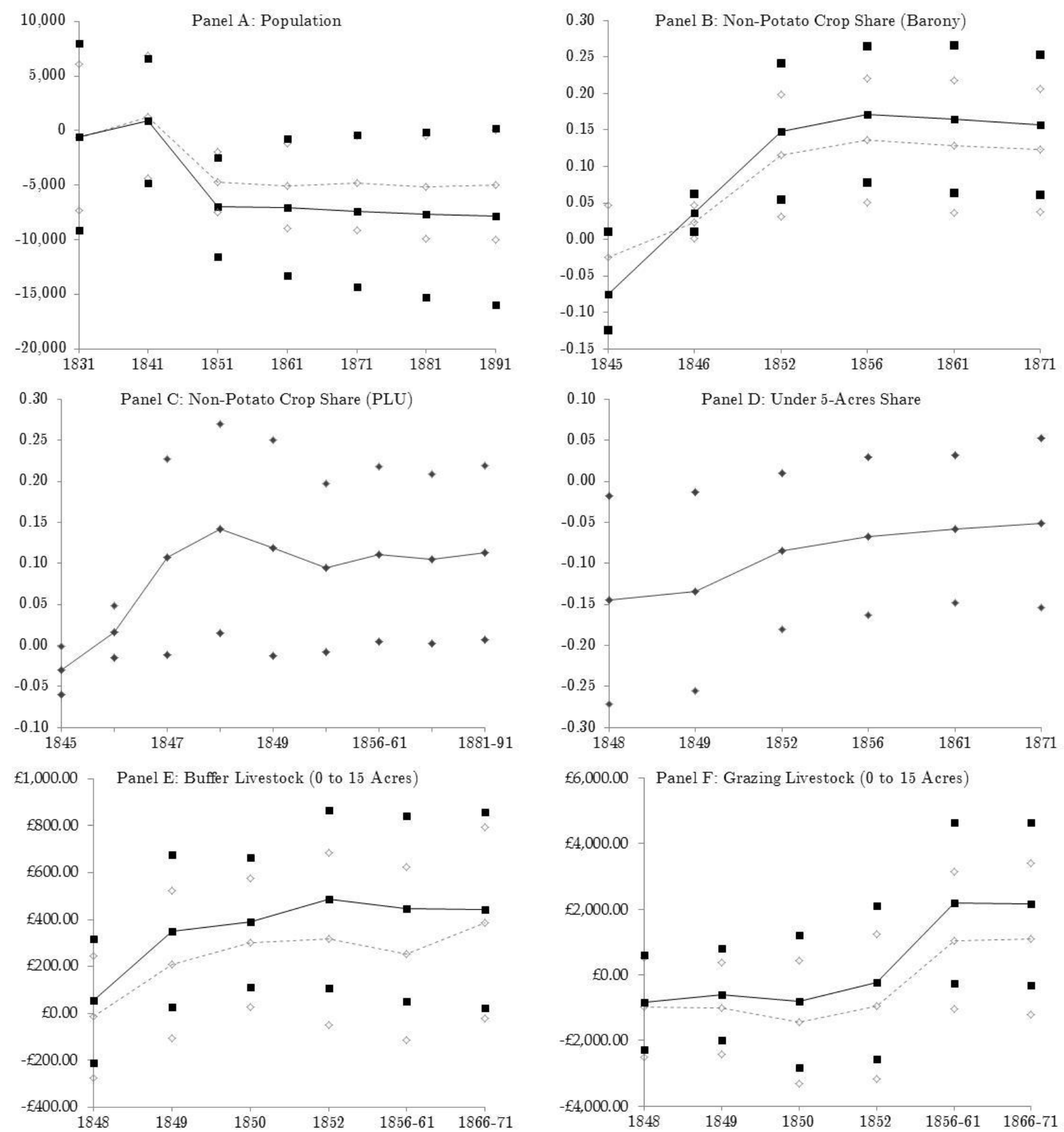

$\ldots-$ Medium vs. Low Blight $\longrightarrow-$ High vs. Low Blight $\longrightarrow$ Medium-High vs. Low-Medium Blight

Notes: Panels A through F graph estimated coefficients ( $\beta_{1 t}$ 's and $\beta_{2 t}$ 's from Eq. (1) and $\beta_{t}$ 's from Eq. (2) in the text), representing differences in changes in the indicated outcome variable in high or medium impact baronies or medium-high impact PLU's relative to low impact baronies or low-medium impact PLU's, respectively. For illustrative purposes, in Panels B and C I reverse the sign on the estimated coefficients for blight severity so as to present estimated relative changes in the fraction of total tillage acreage not under potato crop. $\pm 95 \%$ confidence intervals are scatter plotted in corresponding markers. 


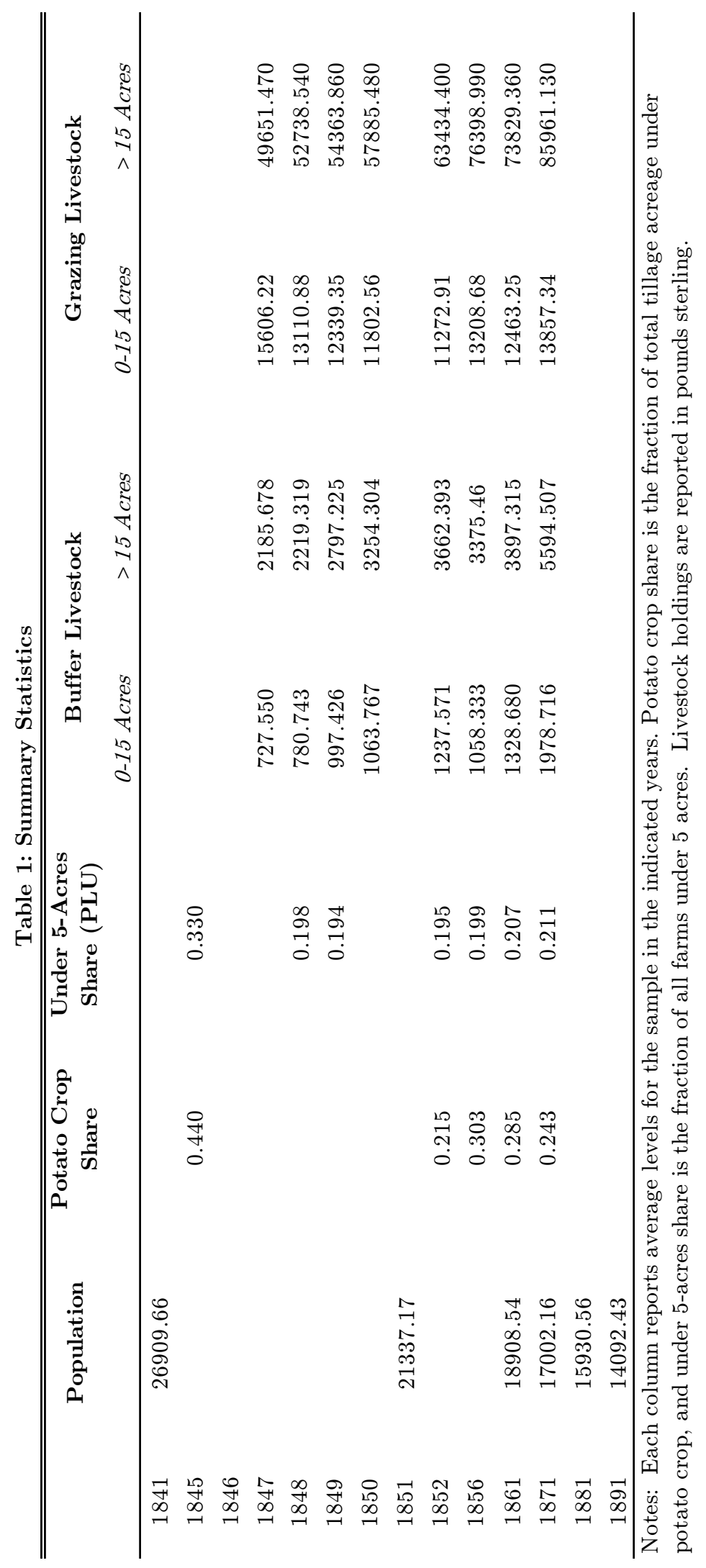


Table 2: Estimated Blight Severity, Loan Fund Presence, Loan Fund Lending, and Musical Society Presence by Pre-Famine Characteristics

\begin{tabular}{|c|c|c|c|c|}
\hline & $\begin{array}{c}\text { Blight Severity } \\
\text { (1) }\end{array}$ & $\begin{array}{c}\text { Loan Fund } \\
(2)\end{array}$ & $\begin{array}{l}\text { Lending } \\
\quad(3)\end{array}$ & $\begin{array}{c}\text { AIMS } \\
(4)\end{array}$ \\
\hline Valuation & $\begin{array}{r}0.000^{*} \\
(0.00)\end{array}$ & $\begin{array}{l}0.000 \\
(0.00)\end{array}$ & $\begin{array}{l}-0.005 \\
(0.01)\end{array}$ & $\begin{array}{l}0.000 \\
(0.00)\end{array}$ \\
\hline Literacy Rate & $\begin{array}{l}0.205 \\
(0.40)\end{array}$ & $\begin{array}{l}-0.384 \\
(0.45)\end{array}$ & $\begin{array}{l}4310.535 \\
(3052.03)\end{array}$ & $\begin{array}{l}0.189 \\
(0.43)\end{array}$ \\
\hline Religious Diversity & $\begin{array}{l}-0.336 \\
(0.73)\end{array}$ & $\begin{array}{l}-0.954 \\
(0.64)\end{array}$ & $\begin{array}{l}-2517.238 \\
(4329.04)\end{array}$ & $\begin{array}{l}-0.258 \\
(0.61)\end{array}$ \\
\hline Population Density & $\begin{array}{l}0.006 \\
(0.02)\end{array}$ & $\begin{array}{l}0.005 \\
(0.02)\end{array}$ & $\begin{array}{c}454.565^{* * *} \\
(139.81)\end{array}$ & $\begin{array}{l}0.024 \\
(0.02)\end{array}$ \\
\hline Fourth-Class Housing & $\begin{array}{l}-0.046 \\
(0.41)\end{array}$ & $\begin{array}{l}-0.423 \\
(0.35)\end{array}$ & $\begin{array}{l}-1301.827 \\
(2379.84)\end{array}$ & $\begin{array}{l}-0.122 \\
(0.34)\end{array}$ \\
\hline Potato Crop Share & $\begin{array}{l}15.689 \\
(46.73)\end{array}$ & $\begin{array}{l}0.647 \\
(0.90)\end{array}$ & $\begin{array}{l}6188.983 \\
(6149.65)\end{array}$ & $\begin{array}{c}0.33 \\
(0.87)\end{array}$ \\
\hline Mean July Air Temp $\left(\mathrm{C}^{\circ}\right)$ & $\begin{array}{l}0.311^{*} \\
(0.16)\end{array}$ & & & \\
\hline Mean July Soil Temp $\left(\mathrm{C}^{\circ}\right)$ & $\begin{array}{l}0.149 \\
(0.16)\end{array}$ & & & \\
\hline Mean July Humidity (\%) & $\begin{array}{c}0.028^{*} \\
(0.02)\end{array}$ & & & \\
\hline \multicolumn{5}{|l|}{ Relief Commission Report } \\
\hline Qualitative v. Quantitative & $\begin{array}{l}0.049 \\
(0.10)\end{array}$ & & & \\
\hline Both v. Quantitative & $\begin{array}{l}-0.133 \\
(0.10) \\
\end{array}$ & & & \\
\hline $\mathrm{N}$ & 206 & 206 & 206 & 206 \\
\hline $\mathrm{R} 2$ & 0.142 & 0.138 & 0.331 & 0.119 \\
\hline
\end{tabular}

Notes: Each column reports OLS estimated coefficients for differences in blight severity, population decline, Loan Fund presence, average annual Loan Fund lending from 1845 to 1850, and AIMS Musical Society presence by prefamine baronial characteristics. Standard errors are reported in parentheses. ${ }^{* * *} \mathrm{p}<0.01,{ }^{* *} \mathrm{p}<0.05,{ }^{*} \mathrm{p}<0.1$ 
Table 3: Estimated Changes in Population, Potato Crop Share, and Farm Size by Blight Severity

Population

Medium vs.

\begin{tabular}{|c|c|c|c|c|c|c|}
\hline & $\begin{array}{c}\text { High vs. Low } \\
(1)\end{array}$ & $\begin{array}{l}\text { Medium vs. } \\
\text { Low } \\
(2)\end{array}$ & $\begin{array}{c}\text { High vs. Low } \\
(3) \\
\end{array}$ & $\begin{array}{l}\text { Medium vs. } \\
\text { Low } \\
(4)\end{array}$ & $\begin{array}{c}\text { Med-High vs. } \\
\text { Low-Med (PLU) } \\
(5)\end{array}$ & $\begin{array}{c}\text { Med-High vs. } \\
\text { Low-Med (PLU) } \\
(6)\end{array}$ \\
\hline 1846 & & & $\begin{array}{c}-0.036^{* * *} \\
(0.01)\end{array}$ & $\begin{array}{c}-0.024^{* *} \\
(0.01)\end{array}$ & $\begin{array}{r}-0.016 \\
(0.02)\end{array}$ & \\
\hline 1847 & & & & & $\begin{array}{c}-0.107^{*} \\
(0.06)\end{array}$ & \\
\hline 1848 & & & & & $\begin{array}{c}-0.142^{* *} \\
(0.06)\end{array}$ & $\begin{array}{c}-0.145^{* *} \\
(0.06)\end{array}$ \\
\hline 1849 & & & & & $\begin{array}{c}-0.119^{*} \\
(0.07)\end{array}$ & $\begin{array}{c}-0.134^{* *} \\
(0.06)\end{array}$ \\
\hline 1851 & $\begin{array}{l}-7004.299^{* * *} \\
(2305.04)\end{array}$ & $\begin{array}{l}-4698.786^{* * *} \\
(1401.03)\end{array}$ & & & & \\
\hline 1852 & & & $\begin{array}{c}-0.148^{* * *} \\
(0.05)\end{array}$ & $\begin{array}{c}-0.115^{* * *} \\
(0.04)\end{array}$ & $\begin{array}{c}-0.095^{*} \\
(0.05)\end{array}$ & $\begin{array}{c}-0.085^{*} \\
(0.05)\end{array}$ \\
\hline 1856 & & & $\begin{array}{c}-0.171^{* * *} \\
(0.05)\end{array}$ & $\begin{array}{c}-0.136^{* * *} \\
(0.04)\end{array}$ & $\begin{array}{c}-0.111^{* *} \\
(0.05)\end{array}$ & $\begin{array}{l}-0.067 \\
(0.05)\end{array}$ \\
\hline 1861 & $\begin{array}{l}-7030.509^{* *} \\
(3178.34)\end{array}$ & $\begin{array}{l}-5091.797^{* *} \\
(1972.81)\end{array}$ & $\begin{array}{c}-0.165^{* * *} \\
(0.05)\end{array}$ & $\begin{array}{c}-0.128^{* * *} \\
(0.05)\end{array}$ & $\begin{array}{c}-0.105^{* *} \\
-0.05\end{array}$ & $\begin{array}{r}-0.058 \\
(0.05)\end{array}$ \\
\hline 1871 & $\begin{array}{l}-7360.487^{* *} \\
(3519.63)\end{array}$ & $\begin{array}{l}-4809.293^{* *} \\
(2205.39)\end{array}$ & $\begin{array}{c}-0.157^{* * *} \\
(0.05)\end{array}$ & $\begin{array}{c}-0.123^{* * *} \\
(0.04)\end{array}$ & $\begin{array}{c}-0.115^{* *} \\
-0.05\end{array}$ & $\begin{array}{l}-0.051 \\
(0.05)\end{array}$ \\
\hline 1891 & $\begin{array}{l}-7859.179^{*} \\
(4088.44)\end{array}$ & $\begin{array}{l}-5002.676^{*} \\
(2536.49)\end{array}$ & & & $\begin{array}{c}-0.113^{* *} \\
(0.05)\end{array}$ & \\
\hline $\mathrm{N}$ & \multicolumn{2}{|c|}{188} & \multicolumn{2}{|c|}{206} & 93 & 93 \\
\hline $\mathrm{R} 2$ & \multicolumn{2}{|c|}{0.671} & \multicolumn{2}{|c|}{0.477} & 0.119 & 0.113 \\
\hline
\end{tabular}

Notes: Each column reports estimated coefficients for changes in population, the fraction of total tillage acres under potato crop, and the fraction of all farmholdings under 5 acres in the indicated year by blight severity. Baronial-level regressions control for available pre-famine observations of the indicated outcome variable, area, partial adult literacy in 1841, total population in 1841, pre-famine baronial valuation, the 1841 share of housing rated fourth class, pre-famine potato acreage as a fraction of total tillage acreage, and PLU and county. PLUlevel regressions control for available pre-famine observations of the indicated outcome variable, area, pre-famine PLU valuation, total population in 1841, pre-famine potato acreage as a fraction of total tillage acreage, and county. Robust standard errors are reported in parentheses and clustered at the baronial or PLU level, respectively. $* * * \mathrm{p}<0.01, * * \mathrm{p}<0.05,{ }^{*} \mathrm{p}<0.1$ 
Table 4: Estimated Changes in Value of Livestock Holdings by Blight Severity

Farms Under 15 Acres

Farms Over 15 Acres

High vs. Low Medium vs. Low High vs. Low Medium vs. Low

(1)

A. Buffer Livestock

1848

$1848-599$

(132.63)

1849

$350.518^{* *}$

(164.89)

1850

1852

$388.594^{* * *}$

(139.95)

$486.334^{* *}$

(192.56)

1856-61 (pooled)

$446.712^{* *}$

(200.68)

1866-71 (pooled)

$441.113^{* *}$

(211.47)

(2)

(3)

(4)

373.164

(461.94)

447.785

(757.67)

307.514

(661.85)

138.931

(459.62)

$-267.275$

(253.13)

$-610.985$

(375.91)

$-600.703^{*}$

(362.88)

B. Grazing Livestock

1848

$-844.649$

$-985.818$

$-532.691$

$-941.168$

(731.92)

(767.02)

(1984.14)

(1996.07)

1849

$-602.019$

$-1016.016$

3042.417

1971.669

(710.60)

(710.62)

(2367.57)

(2329.31)

1850

$-799.001$

$-1441.944$

5962.488

2401.637

(1022.63)

(957.34)

(4257.10)

(4251.43)

1852

$-222.783$

$-965.271$

$-618.859$

$-2958.315$

(1184.76)

(1121.25)

(4717.51)

(4734.08)

1856-61 (pooled)

2185.902*

1048.688

1220.529

$-2044.959$

(1245.66)

(1064.01)

(4248.64)

(4246.38)

1866-71 (pooled)

2159.983*

1088.665

2061.827

$-1957.519$

$\mathrm{N}$

(1260.63)

$\mathrm{R} 2$

0.296 (A) 0.157 (B)

(5083.81)

(5136.33)

Notes: Each column reports estimated coefficients for changes in the value of holdings of buffer (swine and poultry) livestock (Panel A) and grazing (cattle, sheep, and goats) livestock (Panel B), subdivided by farm size, in the indicated year by blight severity. All regressions control for area, partial adult literacy in 1841, 1841 population, pre-famine baronial valuation, the 1841 share of housing rated fourth class, pre-famine potato acreage as a fraction of total tillage acreage, and PLU and county. Estimated coefficients are pooled across the years 1856-61 and 1866-71. Robust standard errors are reported in parentheses and clustered at the baronial level. ${ }^{* * *} \mathrm{p}<0.01,{ }^{* *} \mathrm{p}<0.05,{ }^{*} \mathrm{p}<0.1$ 
Table 5: 2SLS Estimated Changes in Population, Potato Crop Share, and Farm Size by Blight Severity Interacted with Loan Fund Presence or Average Annual Lending

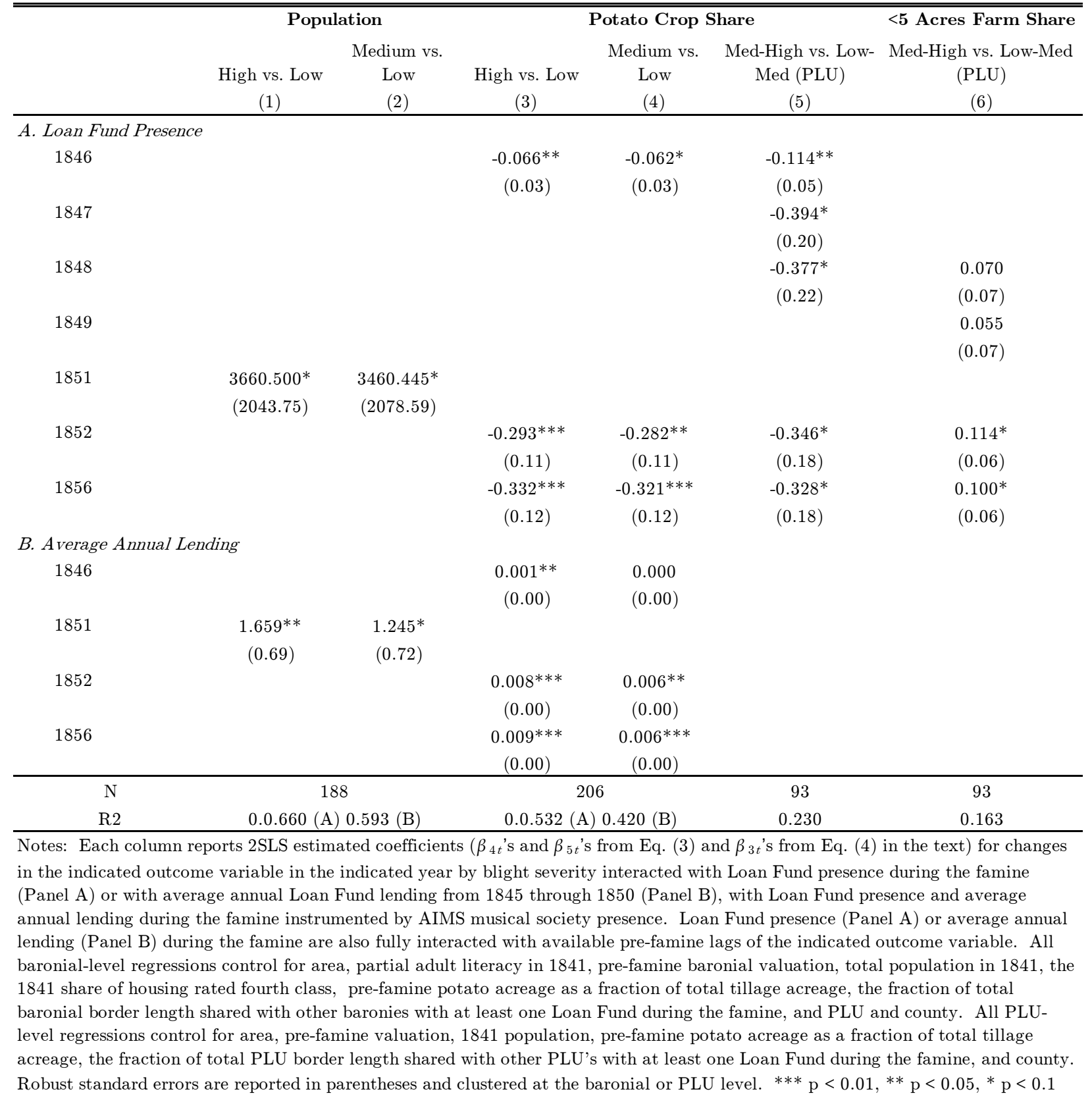


Table 6: Estimated Changes in Population, Potato Crop Share, and Farm Size by Blight Severity, with Instrumented Loan Fund Presence and Lending

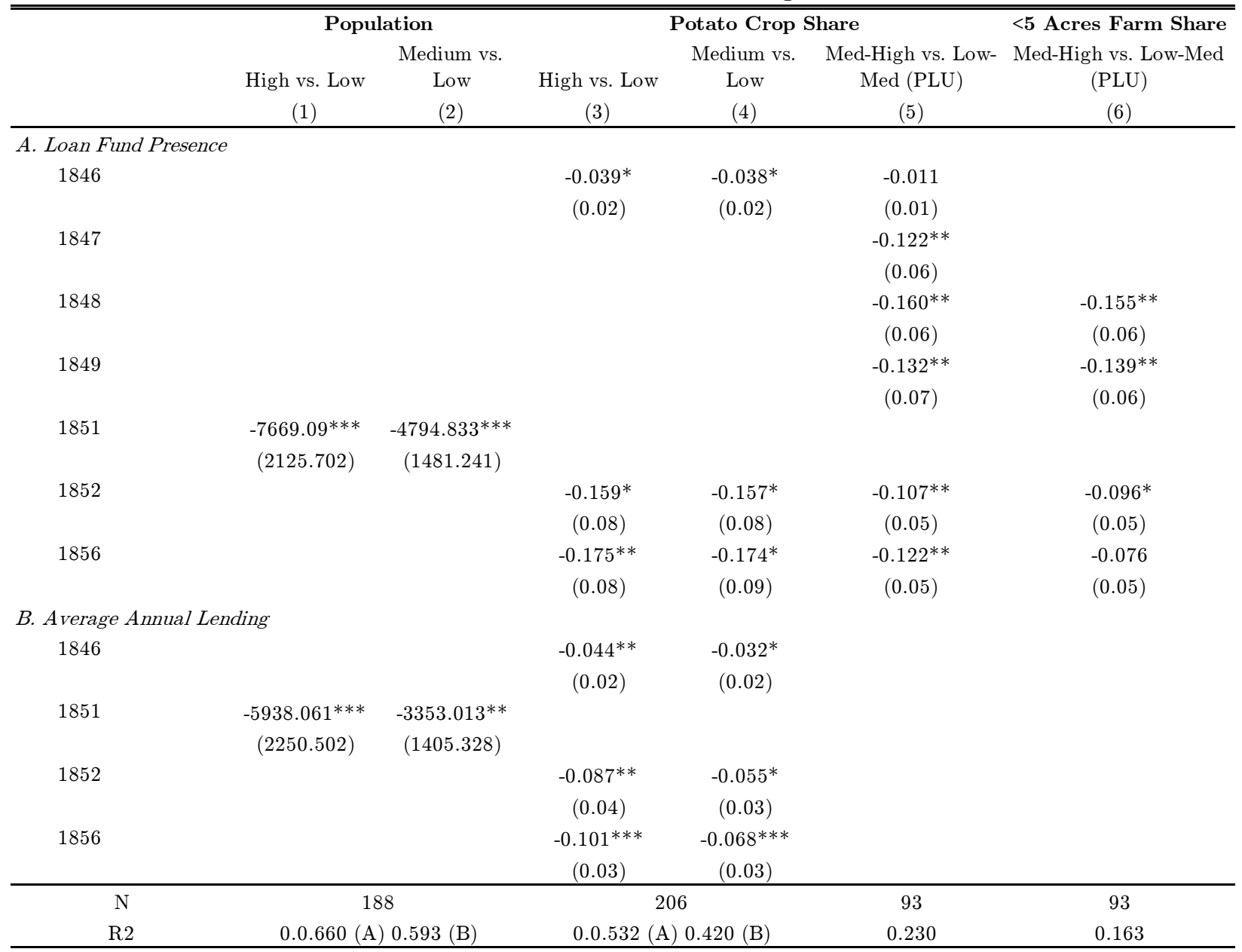

Notes: Each column reports estimated coefficients ( $\beta_{1 t}$ 's and $\beta_{2 t}$ 's from Eq. (3) and $\beta_{t}$ 's from Eq. (4) in the text, representing main effects of blight) for changes in the indicated outcome variable in the indicated year by blight severity, where blight severity is also interacted with Loan Fund presence during the famine (Panel A) or with average annual Loan Fund lending from 1845 through 1850 (Panel B), and Loan Fund presence or average annual lending during the famine instrumented by AIMS musical society presence. Loan Fund presence (Panel A) or average annual lending (Panel B) during the famine are also fully interacted with available prefamine lags of the indicated outcome variable. All baronial-level regressions control for area, partial adult literacy in 1841, prefamine baronial valuation, total population in 1841, the 1841 share of housing rated fourth class, pre-famine potato acreage as a fraction of total tillage acreage, the fraction of total baronial border length shared with other baronies with at least one Loan Fund during the famine, and PLU and county. All PLU-level regressions control for area, pre-famine valuation, 1841 population, prefamine potato acreage as a fraction of total tillage acreage, the fraction of total PLU border length shared with other PLU's with at least one Loan Fund during the famine, and county. Robust standard errors are reported in parentheses and clustered at the baronial or PLU level. ${ }^{* * *} \mathrm{p}<0.01,{ }^{* *} \mathrm{p}<0.05,{ }^{*} \mathrm{p}<0.1$ 
Table 7: First-stage Estimated Coefficients on AIMS Musical Society Presence and AIMS Interacted with Blight Severity

\begin{tabular}{|c|c|c|c|c|c|c|}
\hline & $\begin{array}{l}\text { Fund } \\
(1)\end{array}$ & $\begin{array}{c}\text { Fund } \times \text { Blight- } \\
\text { Medium } \\
(2)\end{array}$ & $\begin{array}{c}\text { Fund } \times \text { Blight- } \\
\text { High } \\
(3)\end{array}$ & $\begin{array}{c}\text { Lending } \\
(4)\end{array}$ & $\begin{array}{c}\text { Lending } \times \text { Blight- } \\
\text { Medium } \\
(5)\end{array}$ & $\begin{array}{c}\text { Lending } \times \text { Blight- } \\
\text { High } \\
(6) \\
\end{array}$ \\
\hline \multicolumn{7}{|l|}{ A. Population } \\
\hline \multirow[t]{2}{*}{ Music } & $1.053^{* * *}$ & 0.063 & -0.010 & 3612.266 & -120.905 & -1771.157 \\
\hline & $(0.12)$ & $(0.08)$ & $(0.08)$ & $(3234.85)$ & $(520.12)$ & $(1872.47)$ \\
\hline \multirow[t]{2}{*}{ Music $\times$ Blight-Medium } & $-0.411^{* * *}$ & $0.608^{* * *}$ & -0.019 & -2918.837 & $1581.673^{* *}$ & 868.218 \\
\hline & $(0.10)$ & $(0.09)$ & $(0.05)$ & $(2821.00)$ & $(756.26)$ & $(1027.11)$ \\
\hline \multirow[t]{2}{*}{ Music $\times$ Blight-High } & $-0.246^{* *}$ & -0.014 & $0.768^{* * *}$ & -482.531 & 236.029 & $4622.191^{* * *}$ \\
\hline & $(0.10)$ & $(0.05)$ & $(0.08)$ & $(2819.49)$ & $(310.49)$ & $(1204.01)$ \\
\hline $\mathrm{N}$ & 188 & 188 & 188 & 188 & 188 & 188 \\
\hline $\mathrm{R} 2$ & 0.560 & 0.661 & 0.700 & 0.351 & 0.350 & 0.445 \\
\hline \multicolumn{7}{|l|}{ B. Potato Crop Share } \\
\hline \multirow[t]{2}{*}{ Music } & $1.025^{* * *}$ & 0.078 & -0.053 & 3321.136 & 190.243 & -2331.512 \\
\hline & $(0.13)$ & $(0.08)$ & $(0.10)$ & $(3272.65)$ & $(377.65)$ & $(2187.07)$ \\
\hline \multirow[t]{2}{*}{ Music $\times$ Blight-Medium } & $-0.425^{* * *}$ & $0.561^{* * *}$ & 0.014 & -2994.914 & $1313.931^{* *}$ & 994.863 \\
\hline & $(0.11)$ & $(0.10)$ & $(0.05)$ & $(2536.29)$ & $(623.29)$ & $(969.29)$ \\
\hline \multirow[t]{2}{*}{ Music $\times$ Blight-High } & $-0.224^{* * *}$ & -0.033 & $0.809^{* * *}$ & -956.981 & 41.917 & $4196.380^{* * *}$ \\
\hline & $(0.08)$ & $(0.04)$ & $(0.07)$ & $(2384.29)$ & $(217.04)$ & $(945.65)$ \\
\hline $\mathrm{N}$ & 206 & 206 & 206 & 206 & 206 & 206 \\
\hline $\mathrm{R} 2$ & 0.544 & 0.620 & 0.701 & 0.303 & 0.328 & 0.406 \\
\hline \multicolumn{7}{|l|}{ C. Livestock } \\
\hline \multirow[t]{2}{*}{ Music } & $0.981^{* * *}$ & 0.005 & -0.01 & $4414.467^{*}$ & -113.994 & -722.566 \\
\hline & $(0.06)$ & $(0.04)$ & $(0.08)$ & $(2242.65)$ & $(242.84)$ & $(780.86)$ \\
\hline \multirow[t]{2}{*}{ Music $\times$ Blight-Medium } & $-0.409^{* * *}$ & $0.588^{* * *}$ & -0.019 & -3273.57 & $1268.758^{* *}$ & 757.799 \\
\hline & $(0.10)$ & $(0.09)$ & $(0.05)$ & $(2321.62)$ & $(623.15)$ & $(756.93)$ \\
\hline \multirow[t]{2}{*}{ Music $\times$ Blight-High } & $-0.215^{* * *}$ & -0.018 & $0.768^{* * *}$ & -966.647 & -89.136 & $4370.712^{* * *}$ \\
\hline & $(0.07)$ & $(0.04)$ & $(0.08)$ & $(2282.83)$ & $(217.81)$ & $(901.03)$ \\
\hline $\mathrm{N}$ & 202 & 202 & 202 & 202 & 202 & 202 \\
\hline $\mathrm{R} 2$ & 0.547 & 0.622 & 0.700 & 0.355 & 0.341 & 0.425 \\
\hline
\end{tabular}

Notes: Each column reports first-stage estimated coefficients at the baronial level for Loan Fund presence and average annual Loan Fund lending from 1845 through 1850 and Loan Fund presence and lending interacted with blight severity, instrumented by AIMS musical society presence, AIMS musical society presence interacted with blight severity and available pre-famine lags of the indicated outcome variable, and the fraction of total baronial border length shared with other baronies with an AIMS musical society. All regressions control for area, partial adult literacy in 1841, pre-famine baronial valuation, total population in 1841, the 1841 share of housing rated fourth class, pre-famine potato acreage as a fraction of total tillage acreage, and PLU and county. Robust standard errors are reported in parentheses and clustered at the baronial level. $* * * \mathrm{p}<0.01,{ }^{* *} \mathrm{p}<0.05,{ }^{*} \mathrm{p}<0.1$ 
Table 8: 2SLS Estimated Changes in Value of Livestock Holdings by Blight Severity Interacted with Loan Fund Presence

\begin{tabular}{|c|c|c|c|c|}
\hline & \multicolumn{2}{|c|}{ Farms Under 15 Acres } & \multicolumn{2}{|c|}{ Farms Over 15 Acres } \\
\hline & $\begin{array}{c}\text { High vs. Low } \\
\text { (1) }\end{array}$ & $\begin{array}{c}\text { Medium vs. Low } \\
\text { (2) }\end{array}$ & $\begin{array}{c}\text { High vs. Low } \\
\text { (3) }\end{array}$ & $\begin{array}{c}\text { Medium vs. Low } \\
\text { (4) }\end{array}$ \\
\hline \multicolumn{5}{|c|}{ A. Buffer Livestock } \\
\hline 1848 & $\begin{array}{c}193.211^{* *} \\
(94.91)\end{array}$ & $\begin{array}{c}157.113^{*} \\
(87.79)\end{array}$ & $\begin{array}{c}-1450.459^{*} \\
(839.43)\end{array}$ & $\begin{array}{c}-1480.063^{*} \\
(837.71)\end{array}$ \\
\hline 1849 & $\begin{array}{l}431.935^{*} \\
(242.67)\end{array}$ & $\begin{array}{l}328.071 \\
(231.93)\end{array}$ & $\begin{array}{l}-2136.56 \\
(1353.05)\end{array}$ & $\begin{array}{l}-2121.841 \\
(1361.38)\end{array}$ \\
\hline 1850 & $\begin{array}{l}349.842 \\
(247.23)\end{array}$ & $\begin{array}{l}313.849 \\
(240.34)\end{array}$ & $\begin{array}{r}-1500.999 \\
(1224.01)\end{array}$ & $\begin{array}{l}-1504.49 \\
(1233.40)\end{array}$ \\
\hline 1852 & $\begin{array}{c}673.227^{* *} \\
(323.42)\end{array}$ & $\begin{array}{c}532.616^{*} \\
(318.24)\end{array}$ & $\begin{array}{r}-980.354 \\
(816.60)\end{array}$ & $\begin{array}{c}-1129.179 \\
(829.58)\end{array}$ \\
\hline 1856 & $\begin{array}{c}549.098^{*} \\
(327.64)\end{array}$ & $\begin{array}{c}338.39 \\
(314.81)\end{array}$ & $\begin{array}{c}-818.931^{* *} \\
(397.49)\end{array}$ & $\begin{array}{c}-982.650^{* *} \\
(403.80)\end{array}$ \\
\hline \multicolumn{5}{|c|}{ B. Grazing Livestock } \\
\hline 1848 & $\begin{array}{c}91.805 \\
(1588.66)\end{array}$ & $\begin{array}{l}1011.561 \\
(1540.03)\end{array}$ & $\begin{array}{c}817.163 \\
(5023.58)\end{array}$ & $\begin{array}{c}830.743 \\
(5090.53)\end{array}$ \\
\hline 1849 & $\begin{array}{c}1182.225 \\
(987.93)\end{array}$ & $\begin{array}{c}1327.150^{*} \\
(750.33)\end{array}$ & $\begin{array}{l}-604.995 \\
(4954.90)\end{array}$ & $\begin{array}{l}-2860.687 \\
(4917.37)\end{array}$ \\
\hline 1850 & $\begin{array}{l}1246.026 \\
(1397.89)\end{array}$ & $\begin{array}{l}1047.958 \\
(1096.63)\end{array}$ & $\begin{array}{c}2657.72 \\
(10266.29)\end{array}$ & $\begin{array}{c}303.123 \\
(10262.28)\end{array}$ \\
\hline 1852 & $\begin{array}{c}958.962 \\
(1806.82)\end{array}$ & $\begin{array}{c}471.898 \\
(1627.73)\end{array}$ & $\begin{array}{c}7255.148 \\
(10716.37)\end{array}$ & $\begin{array}{c}2192.64 \\
(10736.68)\end{array}$ \\
\hline 1856 & $\begin{array}{c}3486.400^{*} \\
(2025.03) \\
\end{array}$ & $\begin{array}{c}3049.080^{*} \\
(1615.17)\end{array}$ & $\begin{array}{l}9572.528 \\
(9757.95) \\
\end{array}$ & $\begin{array}{l}4322.139 \\
(9774.53) \\
\end{array}$ \\
\hline $\mathrm{N}$ & \multicolumn{2}{|c|}{202} & \multicolumn{2}{|c|}{202} \\
\hline $\mathrm{R} 2$ & \multicolumn{2}{|c|}{$0.261(\mathrm{~A}) 0.190(\mathrm{~B})$} & \multicolumn{2}{|c|}{$0.460(\mathrm{~A}) 0.441(\mathrm{~B})$} \\
\hline
\end{tabular}

Notes: Each column reports 2SLS estimated coefficients $\left(\beta_{4 t}\right.$ 's and $\beta_{5 t}$ 's from Eq. (3) in the text) for changes in the value of holdings of buffer (swine and poultry) livestock (Panel A) and grazing (cattle, sheep, and goats) livestock (Panel B), subdivided by farm size, in the indicated year by blight severity interacted with Loan Fund presence during the famine, with Loan Fund presence instrumented by AIMS Musical Society presence. All regressions control for area, partial adult literacy in 1841, 1841 population, pre-famine baronial valuation, the 1841 share of housing rated fourth class, pre-famine potato acreage as a fraction of total tillage acreage, the fraction of total baronial border length shared with other baronies with at least one Loan Fund during the famine, and PLU and county. Robust standard errors are reported in parentheses and clustered at the baronial level. ${ }^{* * *} \mathrm{p}<0.01,{ }^{* *} \mathrm{p}<0.05,{ }^{*} \mathrm{p}<0.1$ 
Table 9: Estimated Changes in Value of Livestock Holdings by Blight Severity, with Instrumented Loan Fund Presence

\begin{tabular}{|c|c|c|c|c|}
\hline & \multicolumn{2}{|c|}{ Farms Under 15 Acres } & \multicolumn{2}{|c|}{ Farms Over 15 Acres } \\
\hline & $\begin{array}{l}\text { High vs. Low } \\
\text { (1) }\end{array}$ & $\begin{array}{c}\text { Medium vs. Low } \\
(2) \\
\end{array}$ & $\begin{array}{c}\text { High vs. Low } \\
(3)\end{array}$ & $\begin{array}{c}\text { Medium vs. Low } \\
(4) \\
\end{array}$ \\
\hline \multicolumn{5}{|c|}{ A. Buffer Livestock } \\
\hline 1848 & $\begin{array}{c}215.330^{* *} \\
(87.63)\end{array}$ & $\begin{array}{c}111.978 \\
(93.65)\end{array}$ & $\begin{array}{c}1353.794 \\
(933.24)\end{array}$ & $\begin{array}{c}1284.812 \\
(935.92)\end{array}$ \\
\hline 1849 & $\begin{array}{c}546.416^{* *} \\
(235.88)\end{array}$ & $\begin{array}{l}389.003 \\
(236.42)\end{array}$ & $\begin{array}{l}1888.925 \\
(1218.90)\end{array}$ & $\begin{array}{l}1758.459 \\
(1219.88)\end{array}$ \\
\hline 1850 & $\begin{array}{c}474.347^{* *} \\
(235.21)\end{array}$ & $\begin{array}{l}360.536 \\
(240.36)\end{array}$ & $\begin{array}{c}1384.301 \\
(916.23)\end{array}$ & $\begin{array}{c}1235.542 \\
(818.71)\end{array}$ \\
\hline 1852 & $\begin{array}{c}747.858^{* *} \\
(316.83)\end{array}$ & $\begin{array}{c}559.447^{*} \\
(317.11)\end{array}$ & $\begin{array}{c}1013.857 \\
(657.38)\end{array}$ & $\begin{array}{l}826.042 \\
(564.17)\end{array}$ \\
\hline 1856 & $\begin{array}{c}612.578^{*} \\
(316.83)\end{array}$ & $\begin{array}{l}456.251 \\
(319.05)\end{array}$ & $\begin{array}{l}559.209 \\
(339.02)\end{array}$ & $\begin{array}{l}328.498 \\
(251.67)\end{array}$ \\
\hline \multicolumn{5}{|c|}{ B. Grazing Livestock } \\
\hline 1848 & $\begin{array}{c}232.264 \\
(1525.75)\end{array}$ & $\begin{array}{l}-1116.465 \\
(1679.25)\end{array}$ & $\begin{array}{l}-826.963 \\
(4877.84)\end{array}$ & $\begin{array}{c}-1463.953 \\
(4935.79)\end{array}$ \\
\hline 1849 & $\begin{array}{l}252.638 \\
(738.81)\end{array}$ & $\begin{array}{l}-1060.55 \\
(1068.35)\end{array}$ & $\begin{array}{l}3962.139 \\
(4408.95)\end{array}$ & $\begin{array}{l}3567.265 \\
(4299.12)\end{array}$ \\
\hline 1850 & $\begin{array}{c}453.892 \\
(1144.60)\end{array}$ & $\begin{array}{l}-923.825 \\
(1307.72)\end{array}$ & $\begin{array}{l}4848.711 \\
(9873.10)\end{array}$ & $\begin{array}{l}2038.171 \\
(9894.84)\end{array}$ \\
\hline 1852 & $\begin{array}{c}487.948 \\
(1606.86)\end{array}$ & $\begin{array}{l}-673.422 \\
(1728.34)\end{array}$ & $\begin{array}{l}-4652.882 \\
(9612.77)\end{array}$ & $\begin{array}{l}-4660.178 \\
(9628.40)\end{array}$ \\
\hline 1856 & $\begin{array}{c}2926.416^{*} \\
(1647.90) \\
\end{array}$ & $\begin{array}{l}1593.514 \\
(1744.17)\end{array}$ & $\begin{array}{r}-4181.126 \\
(9013.83) \\
\end{array}$ & $\begin{array}{r}-5073.327 \\
(8980.89) \\
\end{array}$ \\
\hline $\mathrm{N}$ & \multicolumn{2}{|c|}{202} & \multicolumn{2}{|c|}{202} \\
\hline $\mathrm{R} 2$ & \multicolumn{2}{|c|}{$0.261(\mathrm{~A}) 0.190(\mathrm{~B})$} & \multicolumn{2}{|c|}{$0.460(\mathrm{~A}) 0.441(\mathrm{~B})$} \\
\hline
\end{tabular}

Notes: Each column reports estimated coefficients ( $\beta_{1 t}$ 's and $\beta_{2 t}$ 's from Eq. (3) in the text, representing main effects of blight) for changes in the value of holdings of buffer (swine and poultry) livestock (Panel A) and grazing (cattle, sheep, and goats) livestock (Panel B), subdivided by farm size, in the indicated year by blight severity, with Loan Fund presence instrumented by AIMS Musical Society presence. All regressions control for area, partial adult literacy in 1841, 1841 population, pre-famine baronial valuation, the 1841 share of housing rated fourth class, pre-famine potato acreage as a fraction of total tillage acreage, the fraction of total baronial border length shared with other baronies with at least one Loan Fund during the famine, and PLU and county. Robust standard errors are reported in parentheses and clustered at the baronial level. ${ }^{* * *} \mathrm{p}<0.01,{ }^{* *} \mathrm{p}<0.05,{ }^{*} \mathrm{p}<0.1$ 


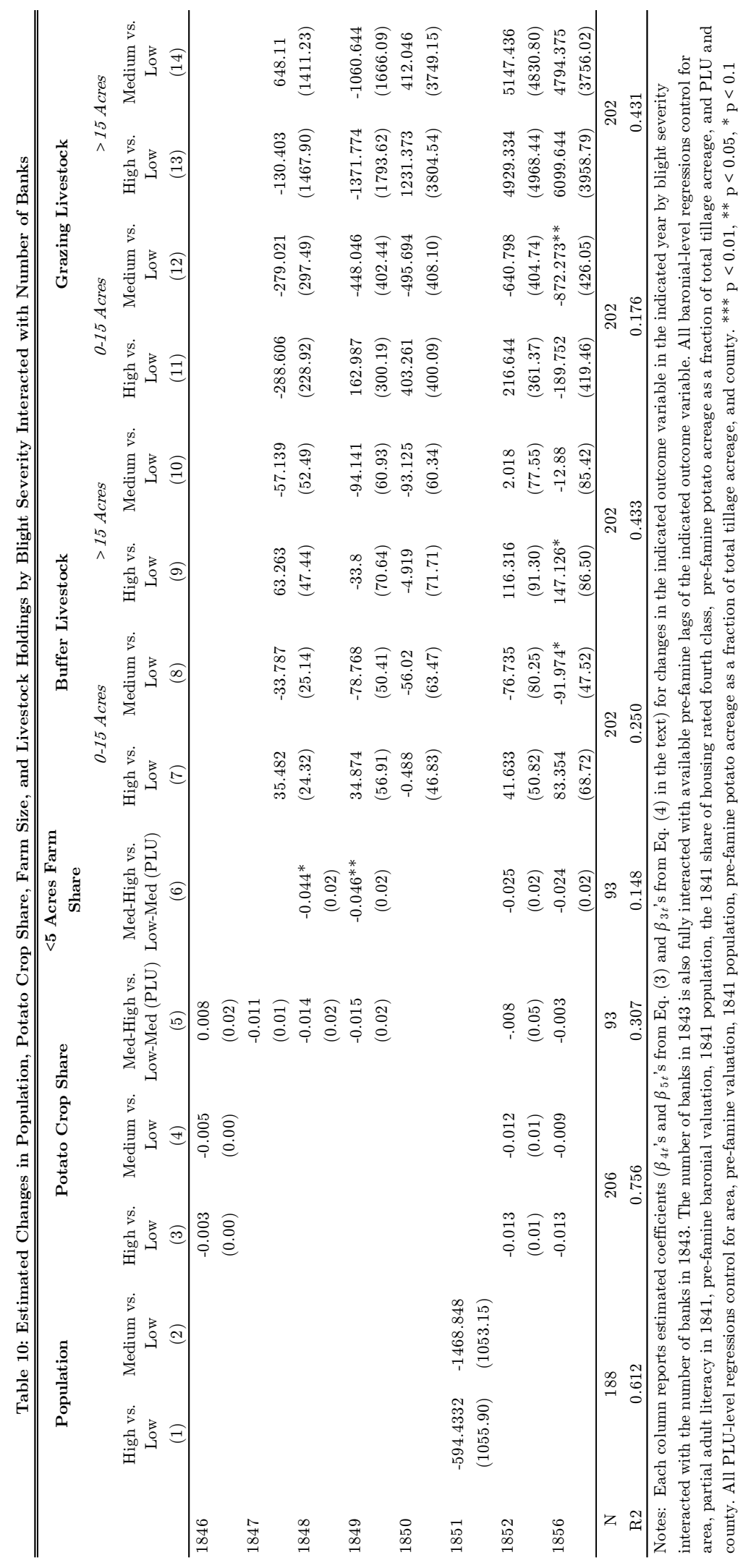


Table 11: Estimated Pre-Famine Changes in Population and Potato Crop Share by Blight Severity and Blight Severity Interacted with Loan Fund Presence

\begin{tabular}{|c|c|c|c|c|}
\hline & \multicolumn{2}{|c|}{ Population } & \multicolumn{2}{|c|}{ Potato Crop Share } \\
\hline & $\begin{array}{c}\text { High vs. Low } \\
(1)\end{array}$ & $\begin{array}{c}\text { Medium vs. Low } \\
(2) \\
\end{array}$ & $\begin{array}{c}\text { High vs. Low } \\
(3)\end{array}$ & $\begin{array}{l}\text { Medium vs. Low } \\
\text { (4) }\end{array}$ \\
\hline \multicolumn{5}{|c|}{ Panel A: Blight Severity } \\
\hline 1831 & $\begin{array}{c}76.925 \\
(2795.77)\end{array}$ & $\begin{array}{c}290.006 \\
(2905.81)\end{array}$ & & \\
\hline 1841 & $\begin{array}{l}-2604.935 \\
(4433.12)\end{array}$ & $\begin{array}{l}-2419.007 \\
(4417.83)\end{array}$ & & \\
\hline 1845 & & & $\begin{array}{l}-0.031 \\
(0.03)\end{array}$ & $\begin{array}{l}0.020 \\
(0.03)\end{array}$ \\
\hline \multicolumn{5}{|c|}{ Panel B: Loan Fund } \\
\hline 1831 & $\begin{array}{l}-2732.072 \\
(5030.36)\end{array}$ & $\begin{array}{l}-2686.892 \\
(4975.08)\end{array}$ & & \\
\hline 1841 & $\begin{array}{r}-2980.203 \\
(7713.23)\end{array}$ & $\begin{array}{r}-3277.569 \\
(7494.91)\end{array}$ & & \\
\hline 1845 & & & $\begin{array}{l}-0.027 \\
(0.04) \\
\end{array}$ & $\begin{array}{l}-0.027 \\
(0.03) \\
\end{array}$ \\
\hline $\mathrm{N}$ & \multicolumn{2}{|c|}{188} & \multicolumn{2}{|c|}{206} \\
\hline $\mathrm{R} 2$ & \multicolumn{2}{|c|}{$0.297(\mathrm{~A}) 0.317(\mathrm{~B})$} & \multicolumn{2}{|c|}{$0.508(\mathrm{~A}) 0.544(\mathrm{~B})$} \\
\hline
\end{tabular}

Notes: Each column in Panel A reports estimated coefficients for changes in population and the fraction of total tillage acres under potato crop in the indicated year by blight severity. All Panel A regressions control for available pre-famine observations of the indicated outcome variable, area, partial adult literacy in 1841, total population in 1841, pre-famine baronial valuation, the 1841 share of housing rated fourth class, pre-famine potato acreage as a fraction of total tillage acreage, and PLU and county. Each column in Panel B reports 2SLS estimated coefficients ( $\beta_{4 t}$ 's and $\beta_{5 t}$ 's from Eq. (3) in the text) for changes in the indicated outcome variable in the indicated year by blight severity interacted with Loan Fund presence during the famine, with Loan Fund presence instrumented by AIMS musical society presence. Loan Fund presence during the famine is also fully interacted with available pre-famine lags of the indicated outcome variable. All Panel B regressions control for area, partial adult literacy in 1841, total population in 1841, pre-famine baronial valuation, the 1841 share of housing rated fourth class, pre-famine potato acreage as a fraction of total tillage acreage, the fraction of total baronial border length shared with other baronies with at least one Loan Fund during the famine, and PLU and county. Robust standard errors are reported in parentheses and clustered at the baronial level. *** $\mathrm{p}<0.01,{ }^{* *} \mathrm{p}<0.05,{ }^{*} \mathrm{p}<0.1$ 